\title{
Sedimentological imprint on subseafloor microbial communities in Western Mediterranean Sea Quaternary sediments
}

\author{
M.-C. Ciobanu ${ }^{1,2,3,4}$, M. Rabineau ${ }^{4}$, L. Droz ${ }^{4}$, S. Révillon ${ }^{4}$, J.-F. Ghiglione ${ }^{5}$, B. Dennielou ${ }^{6}$, S.-J. Jorry ${ }^{6}$, J. Kallmeyer ${ }^{7}$, \\ J. Etoubleau ${ }^{6}$, P. Pignet ${ }^{3,1,2}$, P. Crassous ${ }^{8}$, O. Vandenabeele-Trambouze ${ }^{2,1,3}$, J. Laugier ${ }^{1}$, M. Guégan ${ }^{1}$, A. Godfroy ${ }^{3,1,2}$, \\ and K. Alain ${ }^{2,1,3}$ \\ ${ }^{1}$ Université de Bretagne Occidentale (UBO, UEB), Institut Universitaire Européen de la Mer (IUEM) - UMR 6197, \\ Laboratoire de Microbiologie des Environnements Extrêmes (LMEE), Place Nicolas Copernic, 29280 Plouzané, France \\ ${ }^{2}$ CNRS, IUEM - UMR 6197, Laboratoire de Microbiologie des Environnements Extrêmes (LMEE), Place Nicolas Copernic, \\ 29280 Plouzané, France \\ ${ }^{3}$ Ifremer, UMR6197, Laboratoire de Microbiologie des Environnements Extrêmes (LMEE), Technopôle Pointe du diable, \\ 29280 Plouzané, France \\ ${ }^{4}$ CNRS, IUEM - UMR 6538, Laboratoire Domaines Océaniques, 29280 Plouzané, France \\ ${ }^{5}$ CNRS, Observatoire Océanologique de Banyuls s/mer - UMR 7621, Laboratoire d'Océanographie Microbienne (LOMIC), \\ 66650 Banyuls-sur-Mer, France \\ ${ }^{6}$ Ifremer, Géosciences Marines, 29280 Plouzané, France \\ ${ }^{7}$ Universität Potsdam, Earth and Environmental Sciences, Karl-Liebknecht Str. 25, 14476 Potsdam, Germany \\ ${ }^{8}$ Ifremer, Laboratoire Environnements Profonds, 29280 Plouzané, France \\ Correspondence to: K. Alain (karine.alain@univ-brest.fr)
}

Received: 11 October 2011 - Published in Biogeosciences Discuss.: 9 January 2012

Revised: 22 June 2012 - Accepted: 13 July 2012 - Published: 3 September 2012

\begin{abstract}
An interdisciplinary study was conducted to evaluate the relationship between geological and paleoenvironmental parameters and the bacterial and archaeal community structure of two contrasting subseafloor sites in the Western Mediterranean Sea (Ligurian Sea and Gulf of Lion). Both depositional environments in this area are well-documented from paleoclimatic and paleooceanographic point of views. Available data sets allowed us to calibrate the investigated cores with reference and dated cores previously collected in the same area, and notably correlated to Quaternary climate variations. DNA-based fingerprints showed that the archaeal diversity was composed by one group, Miscellaneous Crenarchaeotic Group (MCG), within the Gulf of Lion sediments and of nine different lineages (dominated by MCG, South African Gold Mine Euryarchaeotal Group (SAGMEG) and Halobacteria) within the Ligurian Sea sediments. Bacterial molecular diversity at both sites revealed mostly the presence of the classes Alphaproteobacteria, Betaproteobacteria and Gammaproteobacteria within Proteobacteria phylum, and also members of Bacteroidetes phylum. The sec-
\end{abstract}

ond most abundant lineages were Actinobacteria and Firmicutes at the Gulf of Lion site and Chloroflexi at the Ligurian Sea site. Various substrates and cultivation conditions allowed us to isolate 75 strains belonging to four lineages: Alpha-, Gammaproteobacteria, Firmicutes and Actinobacteria. In molecular surveys, the Betaproteobacteria group was consistently detected in the Ligurian Sea sediments, characterized by a heterolithic facies with numerous turbidites from a deep-sea levee. Analysis of relative betaproteobacterial abundances and turbidite frequency suggested that the microbial diversity was a result of main climatic changes occurring during the last $20 \mathrm{ka}$. Statistical direct multivariate canonical correspondence analyses (CCA) showed that the availability of electron acceptors and the quality of electron donors (indicated by age) strongly influenced the community structure. In contrast, within the Gulf of Lion core, characterized by a homogeneous lithological structure of upper-slope environment, most detected groups were Bacteroidetes and, to a lesser extent, Betaproteobacteria. At both site, the detection of Betaproteobacteria coincided with increased terrestrial 
inputs, as confirmed by the geochemical measurements ( $\mathrm{Si}$, $\mathrm{Sr}$, Ti and $\mathrm{Ca}$ ). In the Gulf of Lion, geochemical parameters were also found to drive microbial community composition. Taken together, our data suggest that the palaeoenvironmental history of erosion and deposition recorded in the Western Mediterranean Sea sediments has left its imprint on the sedimentological context for microbial habitability, and then indirectly on structure and composition of the microbial communities during the late Quaternary.

\section{Introduction}

Several consistent lines of evidence suggest that environmental characteristics such as geological, geochemical, geophysical and sedimentological properties of sediments are main factors controlling the habitability of the subseafloor sediments. Generally, microbial abundances exponentially decrease with increasing sediment depth (Parkeset al., 2000), particularly due to a decreasing reactivity of organic matter with depth (Middelburg, 1989). However, local increases in microbial activity and microbial effectives as well as population shifts occur in response to specific geochemical conditions (e.g. basaltic aquifer, brine incursion, methanesulfate transition zone, thermogenic gas) (Cragg et al., 1992; D'Hondt et al., 2004; Parkes et al., 2005) and at lithological interfaces (e.g. porous ash layers vs. clay layers, diatomrich sedimentary layers) (Inagaki et al., 2003; Parkes et al., 2005). The mechanical constraints of the sediments such as grain size and porosity are likely to drive the distribution of microorganisms (Rebata-Landa and Santamarina, 2006). Subseafloor microbial metabolic activities are controlled by the bioavailability of energy sources and electron acceptors, themselves correlated to fluid flow regimes (D'Hondt et al., 2004; Engelen et al., 2008). In some sediments, the prokaryotic community composition is correlated to the organic matter bioavailability and/or sediment origin (terrigenous or marine source) (Nunoura et al., 2009). In some Quaternary subseafloor sediments, microbial abundance and activity can be explained by the present hydrogeological situation and organic matter quality, while still reflecting to a certain extent the imprint of past environmental conditions via the sediment structure and geochemical composition (Beck et al., 2011).

If the environmental characteristics act upon the microbial diversity and activity, microorganisms have, conversely, a direct impact on their geological environment. Microorganisms may increase mineral dissolution; release organic/inorganic nutrients and metals that can be used for respiration, anabolism or synthesis of metal-enzymes; and alter the elemental and ionic speciation and distribution, leading sometimes to mineral precipitation (Rogers and Bennett, 2004). Some studies suggested that the biogeographical distribution and diversity of the microbial communities in subsurface sediment are more influenced by environmental control than by geographical separation (Inagaki et al., 2006; Martiny et al., 2006).

The main objective of the present study is to explore the vertical variations in microbial diversity according to environmental characteristics of Mediterranean Sea sediments. We refer here to lithological and geochemical features that reflect paleoenvironmental conditions of sediment deposition. The Mediterranean Sea is a small size basin, particularly sensitive to climatic variations (Rabineau et al., 2005 and references therein). Particularly, continental margins of the Western Mediterranean Sea offer an exceptional preservation of recent climatic changes with high sedimentation rates because of the youth of this small Liguro-Provençal ocean (Rabineau et al., 2006; Sierro et al., 2009). In this region, the subseafloor microbial community composition, diversity and distribution are barely documented, contrary to microbial communities from the water column (Danovaro et al., 2010), surficial sediments (Polymenakou et al., 2005b; Polymenakou et al., 2009), brines (La Cono et al., 2011) or mud volcanoes (Lazar et al., 2011). The aims of this study are (i) to investigate the subsurface microbial diversity associated with both climate-controlled turbiditic sequences (Var Ridge) and upper slope deposits (Gulf of Lion) in the Western Mediterranean Sea, and (ii) to examine the significance of sediment characteristics and paleoenvironmental conditions in determining depth profiles of the microbial community composition.

\section{Material and methods}

\subsection{Study sites and general sampling methods}

The northern part of the Western Mediterranean Sea is characterized by two contrasted continental margins: the Gulf of Lion to the west with a wide and highly sedimented shelf, and the Ligurian margin to the east with a very narrow poorly sedimented shelf (Fig. 1a, b). Three physiographic provinces characterize the Gulf of Lion margin: a wide shelf (with a slope of $\left.0.1^{\circ}\right), 70 \mathrm{~km}$ wide at the most; a continental slope $\left(1.5^{\circ}\right)$; and a rise $\left(0.9^{\circ}\right)$ (Baztan et al., 2005). In contrast, the morphology of the coastal plain of Nice, in the Ligurian Sea, is characterized by a very narrow continental shelf, $2-3 \mathrm{~km}$ wide on average, and a steep continental slope (3.4 to $6.3^{\circ}$ ) leading to water depths of $2000 \mathrm{~m}$ at a distance of less than $20 \mathrm{~km}$ from the coast (Pautot, 1981). Within the Ligurian Sea, the Var turbiditic system extends for $300 \mathrm{~km}$, from the river mouth to the distal area at the base of the northern continental slope of Corsica (Migeon et al., 2006). Cores RHS-KS33 (709 cm length; $42^{\circ} 41^{\prime} .596 \mathrm{~N}, 03^{\circ} 50^{\prime} .493 \mathrm{E}$ ) and KESC930 ( $828 \mathrm{~cm}$ length; $\left.43^{\circ} 23^{\prime} .016 \mathrm{~N}, 07^{\circ} 44^{\prime} .187 \mathrm{E}\right)$ were respectively collected with gravity piston cores (Küllenberg type) on the outer shelf/upper slope ( $291 \mathrm{~m}$ water depth) of the western part of the Gulf of Lion and in the Ligurian Sea at the toe of the slope ( $2160 \mathrm{~m}$ water depth) on top of the Var 


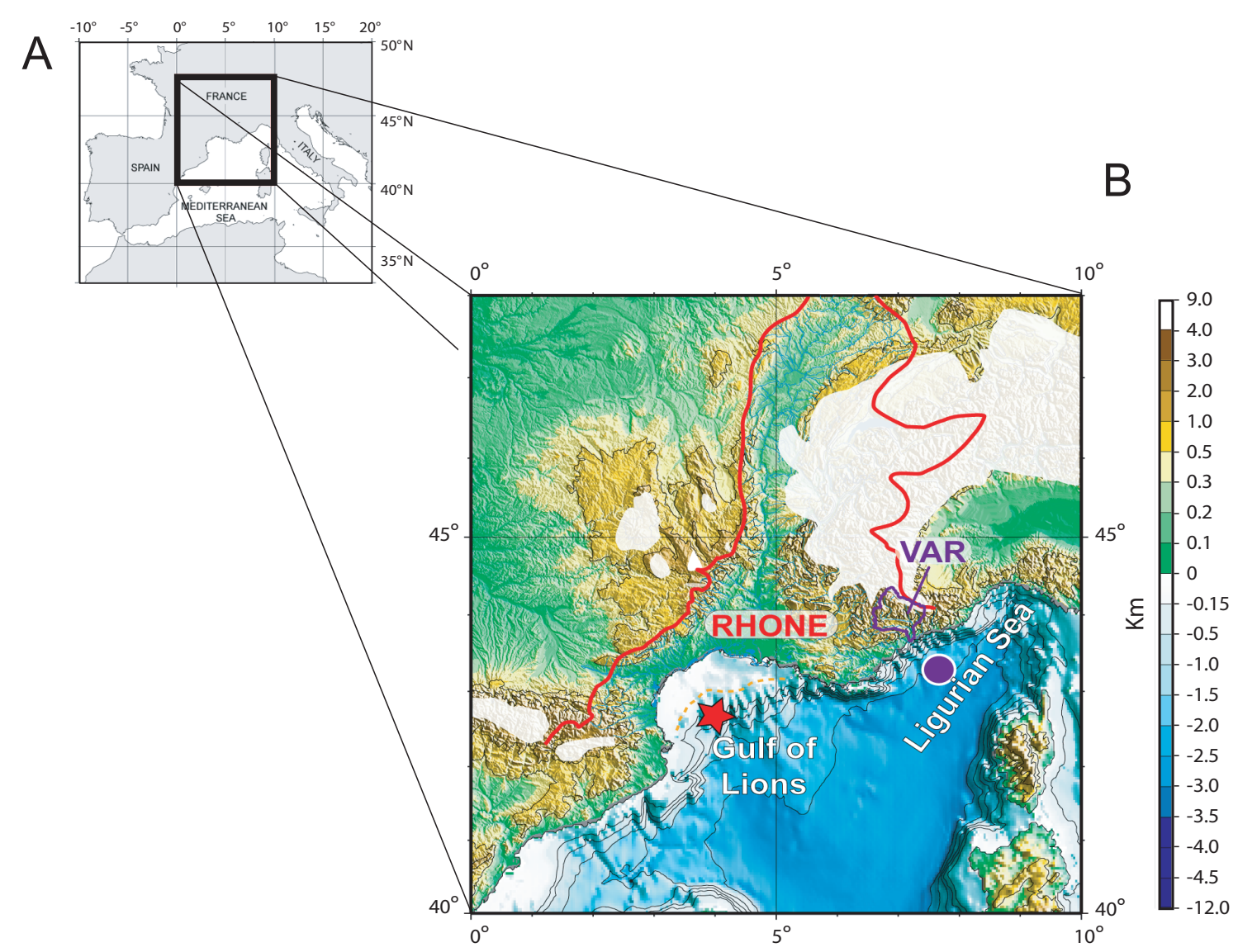

Fig. 1. Morphological and sedimentological background of the studied cores. (A) Location of study area within the Mediterranean Sea. (B) Map of Southern France (modified from Rabineau et al., 2006), showing the continental drainage systems of the Gulf of Lion including mainly the Rhône (red line), and the Var watersheds (purple line) flooding into the Ligurian Sea. In white: maximum extension of the mountainous glaciers during Last Glacial Maximum (LGM-MIS2) (drawn and simplified using data from Ehlers (1996) and Antoine et al. (1999)). Red star: core RHS-KS-33 (Gulf of Lion), Purple dot: core KESC9-30 (Ligurian Sea).

sedimentary ridge (Supplement online Table 1). Both cores were immediately sliced onboard and subsections $(1 \mathrm{~m})$ were stored and transported ( 3 days) at $4{ }^{\circ} \mathrm{C}$. In the laboratory, the core liners were aseptically opened and subsamples for microbial analysis were collected at depth intervals of ca. $20 \mathrm{~cm}$ (core KESC9-30) and ca. $30 \mathrm{~cm}$ (core RHS-KS-33) from the inner part of the cores using cut-off sterile $2 \mathrm{ml}$ syringes, as described elsewhere (Fulthorpe et al., 2011). Subsamples for the molecular analyses were stored at $-80^{\circ} \mathrm{C}$, while subsamples for cultures, cell counts, pore water analyses, sedimentological and geochemical measurements were stored at $4{ }^{\circ} \mathrm{C}$. At both sites, the in situ temperature was estimated from the water temperature measurement (at 291 and $2160 \mathrm{~m}$ ) and the temperature of each core (measured at the bottom of each core, upon arrival of the core on the ship). The estimated in situ temperature was $13-14{ }^{\circ} \mathrm{C}$.

\subsection{Non-destructive analysis of the cores}

After sampling for microbiological and geochemical analyses, the physical properties (gamma ray attenuation (GRA) bulk density, magnetic susceptibility, and P-wave velocity) of the cores were measured non-destructively with the GeotekMSCL (Multi-Sensor Core Logger; United Kingdom), and the density and porosity were determined (Richter et al., 2006). Subsequently, cores were split in half with an automatic core splitter, photographed and visually described according to the grain size (clay, silt, sand), structures (laminations and bioturbation) and content (shells, spots of organic matter). Lithological logs were drawn as well as quantitative cumulative grain size curves. Semi-quantitative elemental composition profiles of sediments were measured using a Core-Scanner (Avaatech, Netherlands) with a $1 \mathrm{~cm}$ step, a current of $0.2 \mathrm{~mA}$, a voltage of 10 and $30 \mathrm{kV}$ and counting time of $20 \mathrm{~s}$. 


\subsection{Sediment and pore water chemistry analyses}

Pore water was obtained by centrifuging approximately $2 \mathrm{~g}$ of sediment for $30 \mathrm{~min}$ at $13000 \mathrm{~g}$ at $4{ }^{\circ} \mathrm{C}$. The pore water was then collected in $2 \mathrm{ml}$ Eppendorf tubes, acidified with nitric acid $(65 \%)$ at $1 / 1000(\mathrm{v} / \mathrm{v})$, and stored at $4{ }^{\circ} \mathrm{C}$ until analysis. $\mathrm{SO}_{4}^{2-}, \mathrm{Cl}^{-}, \mathrm{Na}^{+}, \mathrm{K}^{+}, \mathrm{Mg}^{2+}$, and $\mathrm{Ca}^{2+}$ concentrations were determined by ion exchange chromatography as described in Lazar et al. (2011). Total carbon (TC) content (percentage/dry weight) was analyzed by combustion in a LECO CS 125 carbon analyzer on the pelleted material (ca. $2 \mathrm{~g}$ ) previously extracted and oven-dried $\left(65^{\circ} \mathrm{C}\right)$ for $20 \mathrm{~h}$. The total organic carbon (TOC) was measured in the same way after removing inorganic carbon by progressive and controlled acidification with $\mathrm{HCl}$ (Cauwet, 1981). Quantitative elemental chemical compositions of sediments were determined by Wavelength Dispersive X-Ray Fluorescence spectrometry (WD-XRF; S8 Bruker) on fused beads and compressed powder pellets for major and some trace elements, respectively, as previously described by El Maghraoui et al. (1999). Grain size analyses were performed with a Coulter LS130 laser microgranulometer. Samples (ca. $0.1 \mathrm{~g}$ ) for grain size analysis were carefully collected in every observed laminae for the KESC9-30 core and at the same depths as the microbiological samples (every $30 \mathrm{~cm}$ on average) on the RHS-KS-33 core.

\subsection{Age model}

The age models were established by correlating the calcium records of the studied cores with the calcium records of well dated twin cores previously acquired at the same locations (Supplement online Table 1), using the AnalySeries software (http://www.ncdc.noaa.gov/paleo/softlib/ softlib.html) (Fig. S1). For core RHS-KS-33, we correlated the quantitative calcium profile with the calcium carbonate content of twin core MD99-2348 (Fig. S1a and S1b) (Sierro et al., 2009). Age model of core MD99-2348 is based on 13 calibrated AMS ${ }^{14} \mathrm{C}$ dates for the last $21 \mathrm{ka}$ (Sierro et al., 2009). For core KESC9-30, we correlated scanner calcium profiles with the same data of reference core KNI23 (Fig. S1c and S1d). Age model of core KNI23 is based on 5 calibrated AMS ${ }^{14} \mathrm{C}$ dates for the last 20 ka on KNI23 (Jorry et al., 2011). Both reference cores also had a high-resolution planktonic oxygen isotope stratigraphy on Globigerina bulloides (Sierro et al., 2009; Jorry et al., 2011) which enables close correlation to global climatic changes.

\subsection{Total cell counts}

Total cell counts were performed according to the protocol of Kallmeyer et al. (2008), with some modifications. When necessary, prior to carbonate dissolution step, amorphous silicates were dissolved with hydrofluoric acid (HF) (SigmaAldrich, Deissenhofen, Germany) according to the protocol described by Morono et al. (2009). Cells were stained with SYBR Green I and counted by epifluorescence microscopy using a Leica DMZ2500 microscope with a 100x Plan Fluotar objective and a L5 filter set (Ex. 480/40 Em. 527/30).

\subsection{DNA extractions and PCR amplification}

For each sample, the total community genomic DNA was extracted from ca. $2 \mathrm{~g}$ of wet sediment. Blank DNA extractions were also performed on reagents (no sediment sample) with the same procedure. Cell disruption was performed in a 6770 Freezer/Mill (Spex SamplePrep, NJ, USA) by grinding the sample into a liquid nitrogen chamber. At this step, the sample was first cooled for 2 min in liquid nitrogen then crushed for $1 \mathrm{~min}$ at a beating rate of 8 . After cell disruption, samples were extracted by using a PCI (phe$\mathrm{nol} / \mathrm{chloroform} /$ isoamyl alcohol) protocol. This protocol was described elsewhere (Alain et al., 2011). The nucleic acid precipitation was enhanced by the addition of linear acrylamide (Gaillard and Strauss, 1990). In order to characterize the bacterial and archaeal community depth structure, a polymerase chain reaction-denaturing gradient gel electrophoresis (PCR-DGGE) analysis targeting the V3-V5 region of the 16S rRNA gene was undertaken. A nested PCR was necessary to obtain enough PCR products for DGGE. Bacterial 16S rRNA genes were amplified using the $\mathrm{Bac} 8 \mathrm{~F} / 1492 \mathrm{R}$ (Lane, 1991) and then the 341F-GC/907R (Casamayor et al., 2000) primer combinations. Archaeal 16S rRNA genes were amplified by nested PCR using the following primer combinations: Arc21F/Arc958R (DeLong, 1992) and then Arc344F-GC/Arc915R (Casamayor et al., 2000). The amplification was performed as described elsewhere (Roussel et al., 2009b). In order to limit contamination, all PCR manipulations were carried out under sterile conditions (PCR cabinet; CaptairßBio, Erlab) and all disposable plastic wares were autoclaved and UV treated (40 $\mathrm{min})$ prior to use. Negative controls (PCR mixture without DNA) were included in all sets of PCR reactions to provide a contamination check. A re-amplified negative control from the first round PCR plus a fresh negative control were also included. All negative controls from the first PCR round remained negative after the second PCR amplification step.

\subsection{DGGE and sequencing of DGGE bands}

Denaturing gradient gel electrophoresis (DGGE) analysis was conducted for all sampled depth layers of the two cores as previously described (for details see Roussel et al., 2009a). Different denaturing gradients were used for analyzing the bacterial and archaeal community structure (Supplement information, Fig. S4, S5 and S6). Bands of interest were excised and then sequenced (Beckman-Coulter Cogenics, Stansted). In case of co-migration of different sequences generating a double chromatogram signal, the individual bands were reamplified with the same primer set 
and then migrated on a second DGGE gel using more narrow gradients of 30-35\% and 40-50\%, respectively (Gafan and Spratt, 2005). Sequences were compared to those present in the databases using the BLASTn algorithm (Altschul et al., 1990) and then aligned to their nearest neighbor using the programs CLUSTAL_X and PHYLIP version 3.69 as described elsewhere (Alain et al., 2008). Gene sequences are available at the GenBank/EMBL/DDBJ databases under the accession numbers HE586735 to HE586938 and HE589592 to HE589593.

\subsection{Statistical analysis}

Bacterial DGGE banding patterns were analyzed using the Adobe Illustrator 10.0.3 (http://www.adobe.com) software so as to determine the exact position of a band on the gel, and the ImageJ software package (http://rsbweb.nih.gov/ij/) to determine the intensity of each band, as described by Fromin et al. (2002). Unweighted Pair Group Method with Arithmetic Mean (UPGMA) dendrogram and Multidimensional Scaling (MDS) based on Bray Curtis similarities between normalized DGGE profiles (presence/absence and intensity matrix) were constructed by using the PRIMER v6.0 software (PRIMER-E, Ltd., UK). To investigate relationships between bacterial community structure and environmental parameters, we used a direct gradient approach, canonical correspondence analysis (CCA), using the software package CANOCO version 4.5 for Windows, as previously described by Ghiglione et al. (2008).

\subsection{Enrichment and isolation of microbial strains}

Enrichment cultures were set-up in triplicates from three depth intervals of the RHS-KS33 core (Gulf of Lion): 109$114 \mathrm{~cm}, 478-481 \mathrm{~cm}$ and $698-703 \mathrm{~cm}$.

Aerobic cultures were performed on non-selective and selective media. Solid non-selective media for heterotrophs (Marine Broth 2216 media, BD Difco ${ }^{\mathrm{TM}}$ ) were prepared with two different gelifying agents: agar $(1.5 \% \mathrm{w} / \mathrm{v}$, SigmaAldrich, Deissenhofen, Germany) or Phytagel ${ }^{\mathrm{TM}}(0.8 \%$ w/v, Sigma-Aldrich, Deissenhofen, Germany). Selective solid media for heterotrophs were prepared on the basis of artificial seawater (ASW), amended with one single substrate. The artificial seawater basis contained per litre: $\mathrm{KBr}(0.09 \mathrm{~g}), \mathrm{KCl}$ $(0.6 \mathrm{~g}), \mathrm{CaCl}_{2}(1.47 \mathrm{~g}), \mathrm{MgCl}_{2} \cdot 6 \mathrm{H}_{2} \mathrm{O}(5.67 \mathrm{~g}), \mathrm{NaCl}(30 \mathrm{~g})$, $\mathrm{SrCl}_{2} \cdot 6 \mathrm{H}_{2} \mathrm{O}(0.02 \mathrm{~g}), \mathrm{MgSO}_{4} \cdot 7 \mathrm{H}_{2} \mathrm{O}(5.62 \mathrm{~g}), \mathrm{NaF}(0.002 \mathrm{~g})$, and PIPES buffer $(3 \mathrm{~g})$. The $\mathrm{pH}$ was adjusted to 7.5. After autoclaving, the medium was cooled and the following solutions were added from sterile stock solutions: $\mathrm{NH}_{4} \mathrm{Cl}$ (4.67 mM), $\mathrm{KH}_{2} \mathrm{PO}_{4}(1.5 \mathrm{mM})$, a solution of seven vitamins (1X) (Widdel and Bak, 1992), a trace element solution (1X) (Widdel and Bak, 1992) and a selenite-tungstate solution (1X) (Widdel and Bak, 1992). One of the following substrates was then added to the artificial seawater medium: acetate $(10 \mathrm{mM})$, glucose $(10 \mathrm{mM})$, cellulose $\left(0.5 \mathrm{~g} \mathrm{l}^{-1}\right)$ or chitin $\left(0.5 \mathrm{~g}^{-1}\right)$ (all from Sigma-Aldrich, Deissenhofen, Germany). Selective liquid media for heterotrophs (ASW supplemented with one substrate) containing acetate or glucose (10 mM each) were also prepared.

Selective liquid media for anaerobic incubations were prepared on the basis of ASW as follows: media for fermentative microorganisms contained glucose or pyruvate (10 $\mathrm{mM}$, each) added to ASW prepared without sulfate, and reduced with sterile sodium sulfide $(1.2 \mathrm{mM})$; media for nitrate-reducers were supplemented with $\mathrm{NaNO}_{3}$ and acetate $(10 \mathrm{mM}$, each); and media for sulfate-reducing microorganisms were provided with either a gas phase of $\mathrm{H} 2 / \mathrm{CO}_{2}$ (80/20, 2 bar), or contained pyruvate/fumarate (each at a final concentration of $10 \mathrm{mM}$ ) or acetate (final concentration of $10 \mathrm{mM}$ ). After autoclaving, sulfate-reducing medium was reduced by addition of sterile sodium sulfide $(1.2 \mathrm{mM})$. Production of sulfide was checked through the colorimetric method of Cord-Ruwisch (Cord-Ruwish, 1985). Finally, liquid selective media for methanogens were prepared on the basis of the ASW prepared without sulfate, reduced with sodium sulfide $(1.2 \mathrm{mM})$, and supplemented with either a $\mathrm{H}_{2} / \mathrm{CO}_{2}(80 / 20,2$ bars) gas phase or acetate (final concentration of $10 \mathrm{mM}$ ). The preparation of the anaerobic media and all the manipulations of the anaerobic cultures were performed in an anaerobic chamber (Coy Laboratory Inc.) and media for sulfate-reducing bacteria were prepared as described elsewhere (Widdel and Bak, 1992). All media contained resazurin $\left(0.5 \mathrm{gl}^{-1}\right)$ as an anaerobiosis indicator. The media were inoculated with $1 \%$ sediment slurry and incubated for 3 months, in the dark, at $4{ }^{\circ} \mathrm{C}, 16^{\circ} \mathrm{C}, 20^{\circ} \mathrm{C}$ and $37^{\circ} \mathrm{C}$. As a negative control, uninoculated media were incubated under the same conditions. Growth was routinely monitored by observation of the Petri dishes or by optical microscopy.

Cultivation assays targeting members of the subclass $\mathrm{Be}$ taproteobacteria were performed with samples collected at depth intervals $45-52 \mathrm{~cm}, 101-105 \mathrm{~cm}, 251-256 \mathrm{~cm}, 422-$ $427 \mathrm{~cm}, 583-587 \mathrm{~cm}, 752-757 \mathrm{~cm}$ and $808-813 \mathrm{~cm}$ for the Ligurian Sea core KESC9-30, and with samples collected at depth intervals of 84-88 cm, 198-203 cm, 267-271 cm, 307$312 \mathrm{~cm}$ and $508-512 \mathrm{~cm}$ for the Gulf of Lion core RHS-KS33. These assays were done under aerobic growth conditions on a modified R2A medium (Gomila et al., 2007), containing for 11 of distilled water: $\mathrm{CaCl}_{2}(0.1 \mathrm{~g}), \mathrm{MgSO}_{4} \cdot 7 \mathrm{H}_{2} \mathrm{O}$ $(0.0492 \mathrm{~g}), \mathrm{NaCl}(5 \mathrm{~g})$, yeast extract $(0.5 \mathrm{~g})$, sodium pyruvate $(0.3 \mathrm{~g})$, acid hydrolysate of casein $(0.5 \mathrm{~g})$, pancreatic digest of casein $(0.25 \mathrm{~g})$, meat extract $(0.3 \mathrm{~g})$ and PIPES buffer $(3.4 \mathrm{~g})$. The $\mathrm{pH}$ was adjusted to 7.2 before autoclaving. After autoclaving, $\mathrm{K}_{2} \mathrm{HPO}_{4}\left(5 \mathrm{mll}^{-1}\right)$ and glucose $\left(0.5 \mathrm{gl}^{-1}\right)$ were added to the medium from $1 \mathrm{M}$ sterile stock solutions. Culture media were inoculated with $1 \%$ sediment slurry and incubated at $25^{\circ} \mathrm{C}$ in the dark. Positive enrichment cultures obtained on solid media were purified by repeated streaking on plates. The dilution-to-extinction technique was employed to isolate strains from the liquid cultures. 

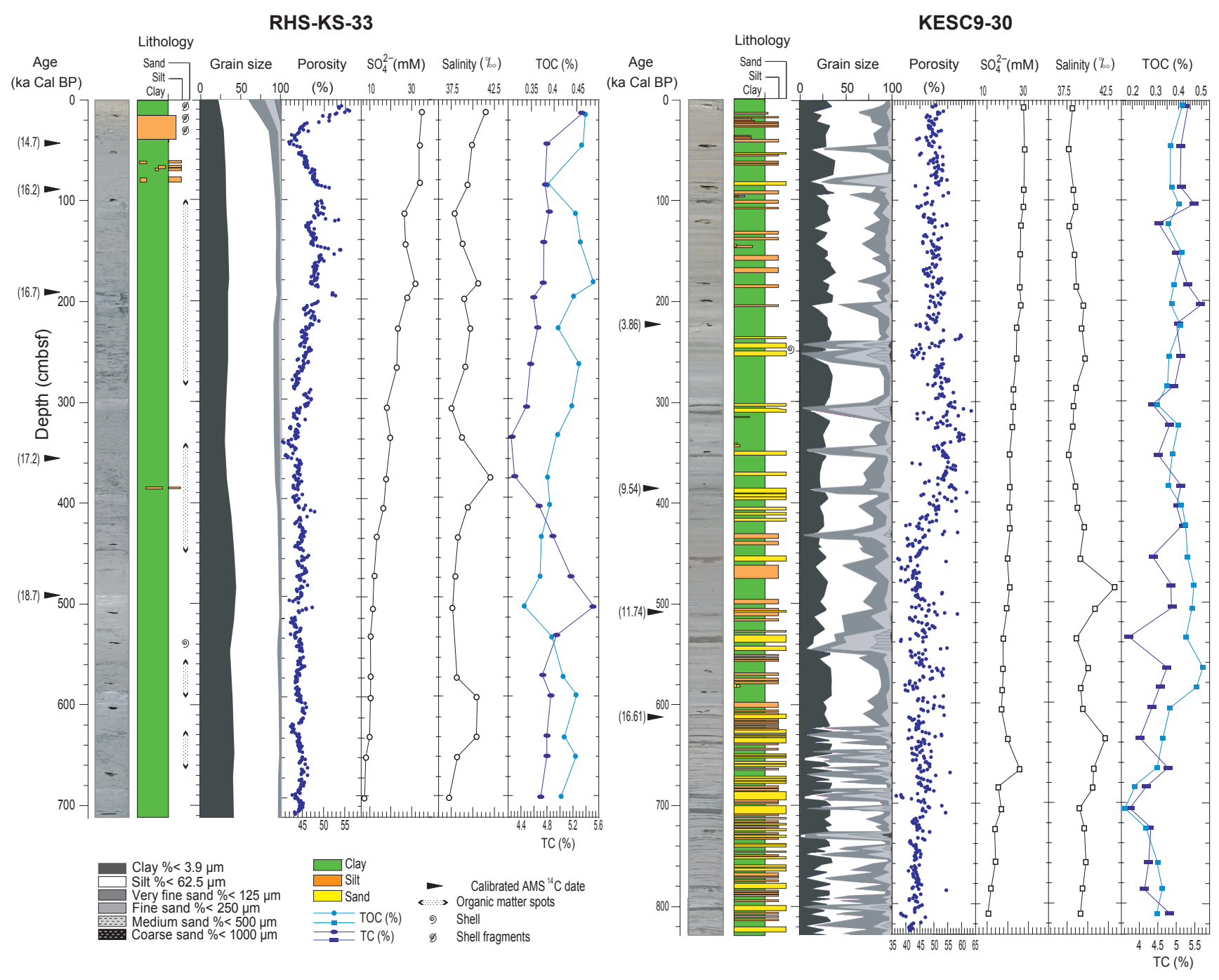

Fig. 2. Principal physicochemical characteristics of studied cores. (TC) total carbon, (light blue) and (TOC) total organic carbon (dark blue).

\section{Results}

\subsection{Sediment structure and paleoenvironment}

Sedimentary facies from Gulf of Lion core RHS-KS-33 were relatively homogeneous and dominated by clay-rich lithologies $(<3.9 \mu \mathrm{m})$ with silty-clay laminaes within the first upper meter, a silt $(<62 \mu \mathrm{m})$ rich layer at the top of the core (between $17-40 \mathrm{~cm}$ ), and very fine to fine sand enrichment in the upper $20 \mathrm{~cm}$. Abundant organic matter spots and bioturbation were observed throughout the core (Fig. 2). TOC content of this core was low and ranged from $0.3 \%$ to $0.5 \%$ (Fig. 2). TC content ranged between $4.6 \%$ and $5.6 \%$, and its profile usually followed the Ca pattern (Fig. 2 and Supplement online Fig. S1, S2). In this core on the Ca profile, one can distinguish a maximum between 440 and $520 \mathrm{~cm}$ (see Supplement online Fig. S1, S2). The sedimentological succession of core KESC9-30 was characterized by major litholog- ical changes compared to core RHS-KS-33. Core KESC9-30 showed alternations of clay rich layers, with abundant planktonic and benthic faunas, and coarse grained layers (silt to coarse sand layers) (Fig. 2). At the top, the core was dominated by numerous silty laminae $(<62.5 \mu \mathrm{m})$ that evolved downcore to thick centimetric to pluri-centimetric fine to medium sand turbidites $(<500 \mu \mathrm{m})$ with locally erosional basal contact (Fig. 2). Clay rich deposits were interpreted as dominantly pelagic intervals, while coarse layers were interpreted as turbidites. TOC was low and ranged from $0.1 \%$ to $0.5 \%$; alternations of organic carbon-rich intervals with carbon-lead intervals were closely correlated with grain-size pattern (Fig. 2). Lowest TOC values $(<0.2 \%)$ occurred in sandy layers, in particular below 600 centimeters, at the bottom of the core (Fig. 2). TC (between $3.5 \%$ and $6 \%$ ) profiles were relatively scattered, especially below 600 centimeters, where the turbidite frequency increased significantly. 


\subsection{Geochemical composition of sediment and pore water}

Along the Gulf of Lion core RHS-KS-33, elemental compositions were fairly homogeneous, with only minor shifts at the top and around $500 \mathrm{~cm}$ (Supplement online Fig. S2, Table S2). Elemental compositions in the Ligurian Sea core KESC9-30 varied downcore and generally followed the lithostratigraphy. Clay-rich intervals were characterized by small variations in the elemental composition of the sediment, compared to sandy-rich intervals, always characterized by the same variations within the elemental composition. Below $600 \mathrm{~cm}$, the silty turbidites were replaced by sandy turbidites (Fig. S2).

At both sites, pore water salinities were generally close to sea water values $(38 \%$ ) and locally increased to more than $42.5 \%$ (Fig. 2). Pore water salinities of the core KESC9-30 were high $(>42.5 \%$ o) in the clay-rich layers $(480-490 \mathrm{~cm})$ and in silty turbidites (around $640 \mathrm{~cm})$, but lower $($ mean $=39.4 \%$ after $500 \mathrm{~cm}$ ) in sandy turbidites. In general, salinity profiles followed the sodium and chloride profiles (Fig. 2 and S3). Sulfate decreased with depth, suggesting that microbial sulfate reduction occurred at both sites. In addition, sulfate and salinity peaks were observed between 633 and $667 \mathrm{~cm}$ of core KESC9-30, indicating that seawater penetrated within this turbiditic layer. Similar to sulfate concentrations, magnesium concentrations decreased with depth.

\subsection{Microbial abundance and community composition}

Total cell numbers were determined by epifluorescence counts at, respectively, ten and seventeen depths in cores RHS-KS-33 and KESC9-30 (Fig. 3). Microbial abundances varied from $5.3 \times 10^{6}$ cells cm$^{-3}(12-17 \mathrm{~cm})$ to $3.7 \times 10^{5}$ cells cm$^{-3}(378-382 \mathrm{~cm})$ in the Gulf of Lion core RHS-KS-33 and between $4.4 \times 10^{6}$ cells cm ${ }^{-3}$ (101$105 \mathrm{~cm})$ and $6.6 \times 10^{5} \mathrm{cells} \mathrm{cm}^{-3}(351-356 \mathrm{~cm})$ in the Ligurian Sea core KESC9-30. At the Gulf of Lion site, the total cell numbers slightly decreased with increasing depth, while at the Ligurian Sea site they remained relatively constant (Fig. 3). Archaea and Bacteria were present in both cores. Bacterial 16S rRNA genes were successfully amplified at all depth along both cores, while archaeal 16S rRNA genes could be amplified from only four depth intervals of core RHS-KS-33 and thirteen depth intervals of core KESC9-30 (Fig. 3). Despite additional trials with different PCR conditions (with additional DNA extracts and decreased annealing temperatures), amplification of archaeal 16S rRNA genes from other depths remained unsuccessful. DGGE was used to determine the depth patterns of the dominant members of microbial communities, and bands were excised to determine taxonomic affiliations. In total, 131 DGGE bands from the two cores were sequenced and used for phylogenetic analyses. At least three bands were excised and sequenced for a given gel position (see Supplement online Fig. S4-6). Bands with equivalent positions in different lanes always corresponded to the same sequence. 117 of the 131 sequenced bands showed $95 \%$ or higher similarity to their closest relative within the GenBank database. Within the 611 bands observed on all DGGE gels (Archaea + Bacteria), $63 \%$ were identified ( $68 \%$ and $65 \%$ of the bacterial bands were respectively identified for the cores KESC9-30 and RHS-KS-33) and used for construction of cumulative bacterial/archaeal plots at each depth (Fig. 3a and b).

\subsubsection{Archaeal communities}

The archaeal diversity of core RHS-KS-33 was exclusively composed of sequences closely related to the Miscellaneous Crenarchaeotic Group (MCG), an uncultivated lineage predominant in 16S rRNA archaeal clone libraries obtained from marine deep subsurface sediments (Fry et al., 2008; Teske and Sørensen, 2008) (Fig. 3a). In core KESC9-30, nine different lineages were present along the core. The most abundant group was MCG (37.8\%) followed by the South African Gold Mine Euryarchaeotic Group 1 (SAGMEG-1; $21.6 \%$ ) and by Halobacteria (16.2\%). In addition, a number of minor uncultivated archaeal groups including the Marine Group I (MGI), the Marine Benthic Group B (MBGB; synonymous with Deep-Sea Archaeal Group (DSAG)), the Marine Benthic Group C (MBGC), the Marine Benthic Group D (MBGD) and the SAGMEG-relatives were retrieved (each representing less than $5.4 \%$ of the sequences). MGI were dominant at the top of the core, while other groups were present at different depths throughout the core (Fig. 3b).

\subsubsection{Bacterial communities}

Bacterial communities presented much more diverse DGGE band profiles than archaeal communities at both sites. The sequenced DGGE bands from the Gulf of Lion core RHSKS-33 belonged to the lineages Bacteroidetes, Proteobacteria (classes Alpha-, Beta- and Gammaproteobacteria), Actinobacteria and Firmicutes. The phylum Bacteroidetes (29.6\% of total bacterial relative abundances) dominated almost all depth intervals, except the surface layers (12$17 \mathrm{~cm}$ ) where it represented less than $20 \%$ of the diversity. Within the Proteobacteria, the class Betaproteobacteria $(18.3 \%)$ was the second-most abundant lineage at this site with sequences belonging to three families (Burkholderiaceae, Ralstoniaceae and Comamonadaceae). Betaproteobacteria were encountered at almost all depths, except at $84-88 \mathrm{~cm}$ and $307-312 \mathrm{~cm}$ (Fig. 3a). Sequences belonging to the phylum Actinobacteria $(7.5 \%)$ grouped within one single family (Propionibacteriaceae), while the phylum Firmicutes $(6.1 \%)$ was represented by three families (Clostridiaceae, Veillonellaceae and Staphylococcaceae). Sequences belonging to the classes Alpha- and Gammaproteobacteria rarely occurred at this site $(<3 \%)$. Overall, sequences of this core 

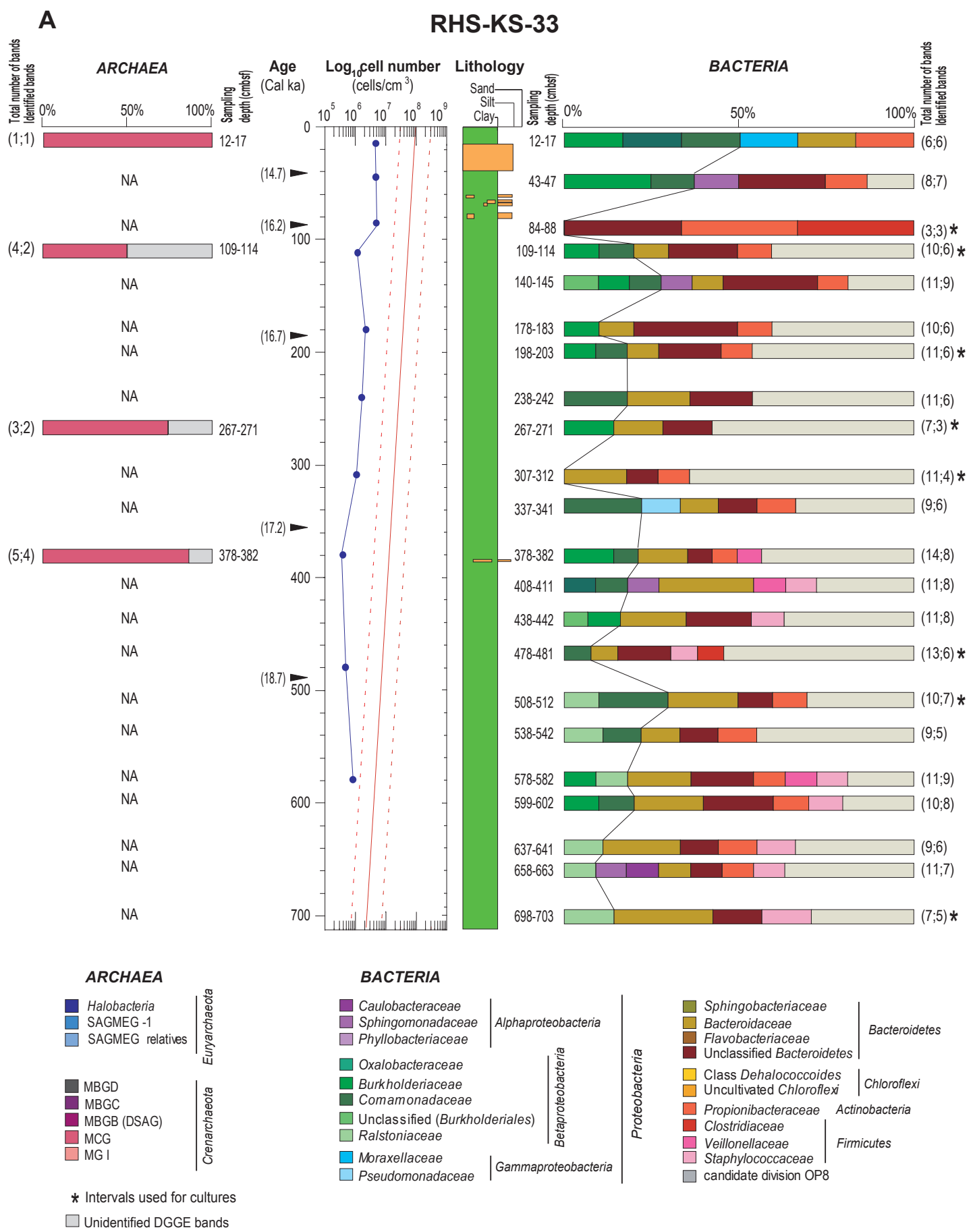

Fig. 3a. Depth distribution of the bacterial and archaeal community structures based on 16S rRNA gene, and total cell numbers compared with the lithological structure, in the Gulf of Lion and the Ligurian Sea. The column diagrams represent the cumulative percentages of bacterial and archaeal phylotypes detected at the two sites: (A) Gulf of Lion (RHS-KS-33), (B) Ligurian Sea (KESC9-30). The relative abundance of different families represents the sum of taxa detected after sequencing of DGGE bands reported in the total number of sequences observed on each lane of the DGGE gels. The phylogenetic affiliation of each band sequence was determined by similarity analysis. The total number of bands observed at each sampled interval and the total number of identified bands are given in parentheses on the left of the bars. The black line in the right part of the diagrams separates the Betaproteobacterial sequences from other bacterial sequences. The solid red curve represents the general depth distribution of subsurface bacterial populations, with $95 \%$ upper and lower prediction limits shown by dashed red curves (from Parkes and collaborators, 2000). Abbreviations: cmbsf, centimeters below the seafloor; NA, not amplified; SAGMEG-1, South African Gold Mine Euryarchaeotal Group 1; MBGD, Marine Benthic Group D; MBGB, Marine Benthic Group B; MCG, Miscellaneous Crenarchaeotic Group; MGI, Marine Group I. 
B

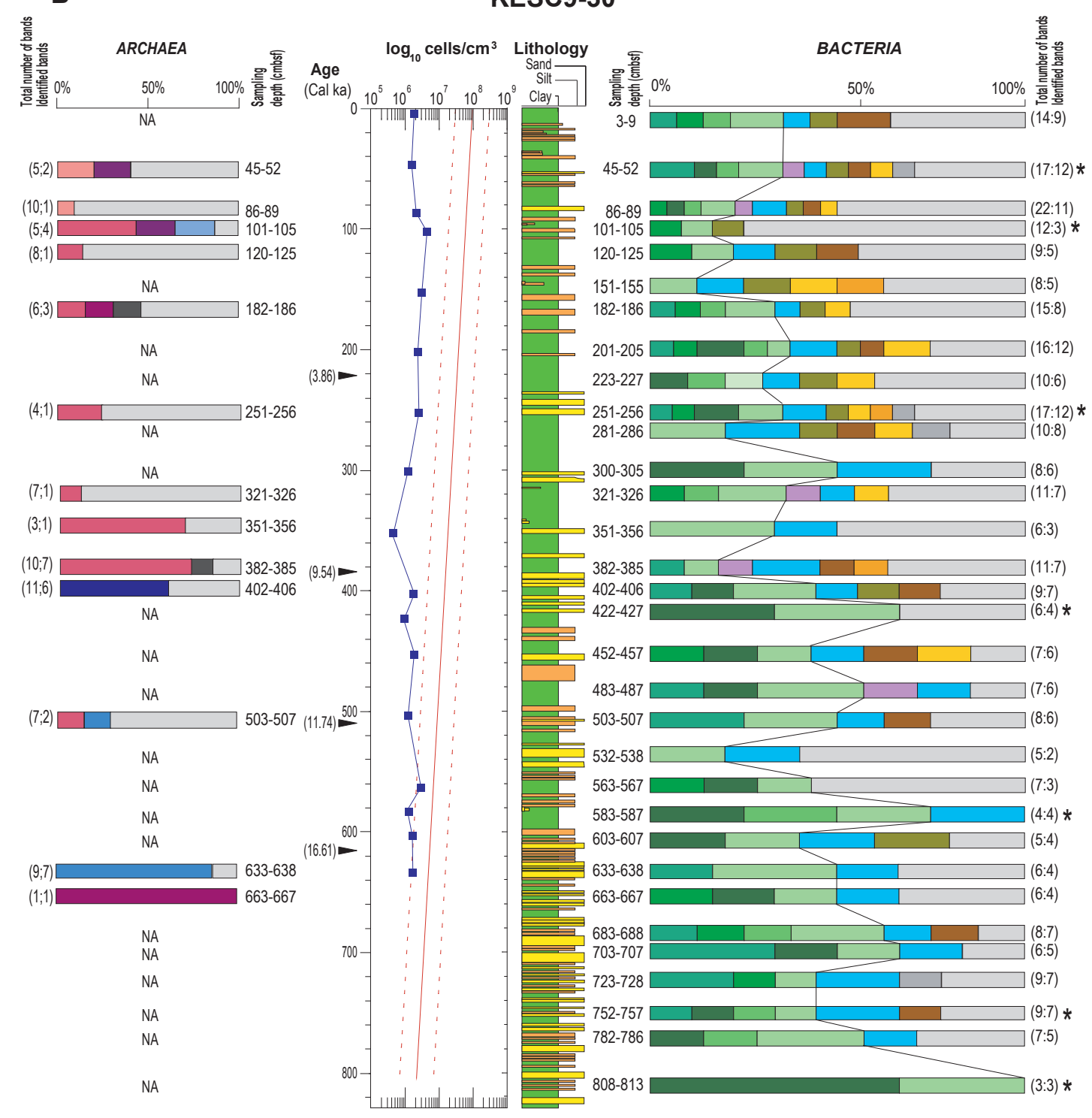

KESC9-30 Clay 7 言

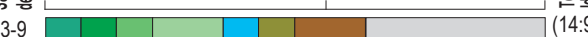
$45-52$

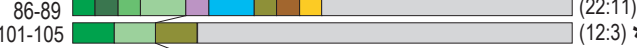
120-125 \begin{tabular}{l|l|l|l|l}
\hline $151-155$ \\
\hline
\end{tabular}$$
201-205 \square(16: 12)
$$

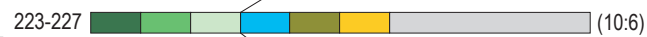

(2) $351-$

\begin{tabular}{l}
$382-385$ \\
\hline
\end{tabular}
* Intervals used for cultures $\square$ Unidentified DGGE bands

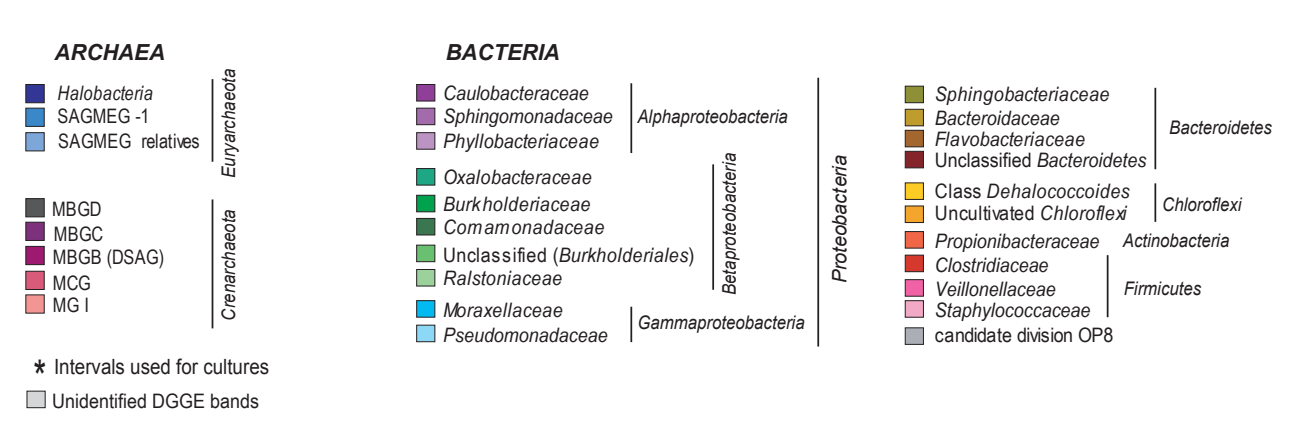

Fig. 3b. Continued.

were closely related to ubiquitous microorganisms previously recovered from marine or terrestrial environments contaminated with heavy metals (Selenska-Pobell et al., 2001; Akob et al., 2007; Bruun et al., 2010; Kampe et al., 2010), from soil (Phuong et al., 2008; Schouten et al., 2010), water, groundwater (Sahl et al., 2008) and petroleum crude oil samples (Yamane et al., 2008). 
Table 1. 16S ribosomal DNA sequence similarity analysis of cultured isolates from cores KESC9-30 and RHS-KS-33.

\begin{tabular}{|c|c|c|c|c|c|c|}
\hline Sequence type & Accession No & $\begin{array}{c}\text { No of } \\
\text { isolates }\end{array}$ & $\begin{array}{l}\text { Depth origin } \\
(\mathrm{cmbsf})^{*}\end{array}$ & Culture conditions & $\begin{array}{l}\text { Closest cultured genus } \\
\text { (\% BLASTn identity) }\end{array}$ & Taxonomic affiliation \\
\hline \multicolumn{7}{|l|}{ Gulf of Lion } \\
\hline & & & & & & Alphaproteobacteria \\
\hline RHS-str.Ne D & HE589592 & 1 & 109 & MB2216-agar, $\mathrm{O}_{2}, 20^{\circ} \mathrm{C}$ & Pelagicola sp. $(96.5 \%)$ & Rhodobacteraceae \\
\hline RHS-str.108_Ne E & HE586857 & 1 & 109 & MB2216-agar, $\mathrm{O}_{2}, 4^{\circ} \mathrm{C}$ & Pelagicola sp. $(96.4 \%)$ & Rhodobacteraceae \\
\hline RHS-str.305 & HE586858 & 6 & 109,478 & Acetate-agar, $\mathrm{O}_{2}, 20^{\circ} \mathrm{C}$ or $37^{\circ} \mathrm{C}$ & Phaeobacter sp. (99\%) & Rhodobacteraceae \\
\hline RHS-str.307 & HE586859 & 1 & 109 & Acetate-agar, $\mathrm{O}_{2}, 20^{\circ} \mathrm{C}$ & Phaeobacter sp. (98\%) & Rhodobacteraceae \\
\hline RHS-str.404 & HE589593 & 2 & 109,478 & Glucose-agar, $\mathrm{O}_{2}, 20^{\circ} \mathrm{C}$ & Phaeobacter sp. (98\%) & Rhodobacteraceae \\
\hline RHS-str.502 & HE586860 & 2 & 109,478 & Pyruvate fermentation & Sphingomonas sp. $(91 \%)$ & \\
\hline \multirow[t]{2}{*}{ RHS-str.509 } & HE586861 & 2 & 478 & Glucose fermentation, 20 or $37^{\circ} \mathrm{C}$ & Sphingomonas sp. $(89 \%)$ & \\
\hline & & & & & & Gammaproteobacteria \\
\hline RHS-str.102_2EC & HE586862 & 1 & 109 & MB2216-agar, $\mathrm{O}_{2}, 37^{\circ} \mathrm{C}$ & Marinobacter sp. (99\%) & Alteromonadaceae \\
\hline RHS-str.103_3BL & HE586863 & 1 & 109 & MB2216-agar, $\mathrm{O}_{2}, 37^{\circ} \mathrm{C}$ & Marinobacter sp. (99\%) & Alteromonadaceae \\
\hline RHS-str.104_4JA & HE586864 & 2 & 109,478 & MB2216-agar, $\mathrm{O}_{2}, 37^{\circ} \mathrm{C}$ & Idiomarina sp. (99\%) & Idiomarinaceae \\
\hline RHS-str.105_5CR & HE586865 & 3 & $109,478,698$ & MB2216-agar, $\mathrm{O}_{2}, 37^{\circ} \mathrm{C}$ & Halomonas sp. (99\%) & Halomonadaceae \\
\hline RHS-str.106_6PE & HE586866 & 2 & 109,478 & MB2216-agar, $\mathrm{O}_{2}, 20$ or $37^{\circ} \mathrm{C}$ & Halomonas sp. (99\%) & Halomonadaceae \\
\hline RHS-str.7RO & HE586867 & 1 & 478 & MB2216-agar, $\mathrm{O}_{2}, 16^{\circ} \mathrm{C}$ & Shewanella sp. (99\%) & Shewanellaceae \\
\hline RHS-str.Or F & HE586868 & 2 & 109,478 & MB2216-agar, $\mathrm{O}_{2}, 4^{\circ} \mathrm{C}$ or $20^{\circ} \mathrm{C}$ & Halomonas sp. $(99 \%)$ & Halomonadaceae \\
\hline RHS-str.Br_G & HE586869 & 1 & 109 & MB2216-agar, $\mathrm{O}_{2}, 4^{\circ} \mathrm{C}$ & Pseudoalteromonas sp. (99\%) & Pseudoalteromonadaceae \\
\hline RHS-str.202_Mar A & HE586870 & 4 & 109,478 & MB2216-phytagel, $\mathrm{O}_{2}, 20$ or $37^{\circ} \mathrm{C}$ & Marinobacter sp. $(99 \%)$ & Alteromonadaceae \\
\hline RHS-str. 203_Cr B & HE586871 & 5 & $109,478,698$ & MB2216-phytagel, $\mathrm{O}_{2}, 20$ or $37^{\circ} \mathrm{C}$ & Halomonas sp. $(99 \%)$ & Halomonadaceae \\
\hline RHS-str.204_Cr C & HE586872 & 2 & 109,478 & MB2216-phytagel, $\mathrm{O}_{2}, 37^{\circ} \mathrm{C}$ & Halomonas sp. (99\%) & Halomonadaceae \\
\hline RHS-str.402 & HE586873 & 2 & 109,478 & Glucose-agar, $\mathrm{O}_{2}, 20^{\circ} \mathrm{C}$ & Pseudoalteromonas sp. (99\%) & Pseudoalteromonadaceae \\
\hline RHS-str.403 & HE586874 & 4 & $109,478,698$ & Glucose-agar, $\mathrm{O}_{2}, 20^{\circ} \mathrm{C}$ or $37^{\circ} \mathrm{C}$ & Halomonas sp. (99\%) & Halomonadaceae \\
\hline RHS-str.405 & HE586875 & 4 & 109,478 & Glucose-agar, $\mathrm{O}_{2}, 20^{\circ} \mathrm{C}$ or $37^{\circ} \mathrm{C}$ & Pseudoalteromonas sp. (99\%) & Pseudoalteromonadaceae \\
\hline RHS-str.X_19b & HE586876 & 1 & 109 & Glucose-agar, $\mathrm{O}_{2}, 20^{\circ} \mathrm{C}$ & Halomonas sp. $(99 \%)$ & Halomonadaceae \\
\hline RHS-str.406 & HE586877 & 2 & 109,478 & Glucose-agar, $\mathrm{O}_{2}, 20^{\circ} \mathrm{C}$ & Pseudoalteromonas sp. (99\%) & Pseudoalteromonadaceae \\
\hline RHS-str.407 & HE586878 & 3 & $109,478,698$ & Glucose-agar, $\mathrm{O}_{2}, 20^{\circ} \mathrm{C}$ & Pseudoalteromonas sp. (99\%) & Pseudoalteromonadaceae \\
\hline RHS-str.409 & HE586879 & 3 & 109,478 & Glucose-agar, $\mathrm{O}_{2}, 20^{\circ} \mathrm{C}$ or $37^{\circ} \mathrm{C}$ & Pseudoalteromonas sp. (99\%) & Pseudoalteromonadaceae \\
\hline RHS-str.301 & HE586880 & 2 & 109,478 & Acetate-agar, $\mathrm{O}_{2}, 20^{\circ} \mathrm{C}$ or $37^{\circ} \mathrm{C}$ & Marinobacter sp. $(99 \%)$ & Alteromonadaceae \\
\hline RHS-str.302 & HE586881 & 4 & 109,478 & Acetate-agar, $\mathrm{O}_{2}, 20^{\circ} \mathrm{C}$ or $37^{\circ} \mathrm{C}$ & Halomonas sp. $(100 \%)$ & Halomonadaceae \\
\hline RHS-str.303 & HE586882 & 1 & 478 & Acetate-agar, $\mathrm{O}_{2}, 37^{\circ} \mathrm{C}$ & Alcanivorax sp. $(99 \%)$ & Alcanivoracaceae \\
\hline RHS-str.304 & HE586883 & 1 & 478 & Acetate-agar, $\mathrm{O}_{2}, 20^{\circ} \mathrm{C}$ & Marinobacter sp. (99\%) & Alteromonadaceae \\
\hline RHS-str.308 & HE586884 & 1 & 478 & Acetate-agar, $\mathrm{O}_{2}, 20^{\circ} \mathrm{C}$ & Halomonas sp. $(99 \%)$ & Halomonadaceae \\
\hline RHS-str.90 & HE586885 & 1 & 84 & Modified R2A medium, $\mathrm{O}_{2}, 25^{\circ} \mathrm{C}$ & Aeromonas sp. (99\%) & Aeromonadaceae \\
\hline RHS-str. 220 & HE586886 & 1 & 198 & Modified R2A medium, $\mathrm{O}_{2}, 25^{\circ} \mathrm{C}$ & Pseudomonas sp. (99\%) & $\begin{array}{l}\text { Pseudomonadaceae } \\
\text { Firmicutes }\end{array}$ \\
\hline RHS-str. 320 & HE586887 & 1 & 307 & Modified R2A medium, $\mathrm{O}_{2}, 25^{\circ} \mathrm{C}$ & Bacillus sp. (99\%) & Bacillaceae Actinobacteria \\
\hline RHS-str.520 & HE586888 & 1 & 508 & Modified R2A medium, $\mathrm{O}_{2}, 25^{\circ} \mathrm{C}$ & Brevibacterium sp. (99\%) & Brevibacteraceae \\
\hline \multicolumn{7}{|l|}{ Ligurian Sea } \\
\hline & & & & & & Gammaproteobacteria \\
\hline ESC-str.110 & HE586889 & 1 & 101 & Modified R2A medium, $\mathrm{O}_{2}, 25^{\circ} \mathrm{C}$ & Halomonas sp. (99\%) & Halomonadaceae \\
\hline ESC-str.770 & HE586890 & 1 & 752 & Modified R2A medium, $\mathrm{O}_{2}, 25^{\circ} \mathrm{C}$ & Pseudomonas sp. (99\%) & $\begin{array}{l}\text { Pseudomonadaceae } \\
\text { Firmicutes }\end{array}$ \\
\hline ESC-str.50 & HE586891 & 1 & 45 & Modified R2A medium, $\mathrm{O}_{2}, 25^{\circ} \mathrm{C}$ & Bacillus sp. (99\%) & $\begin{array}{l}\text { Bacillaceae } \\
\text { Actinobacteria }\end{array}$ \\
\hline ESC-str.590 & HE586892 & 1 & 583 & Modified R2A medium, $\mathrm{O}_{2}, 25^{\circ} \mathrm{C}$ & Brevibacterium sp. (99\%) & Brevibacteraceae \\
\hline
\end{tabular}

* cmbsf: centimeters below the seafloor

Bacterial communities of the Ligurian Sea core KESC9-30 were composed of Proteobacteria (classes Alpha-, Beta- and Gammaproteobacteria), Chloroflexi, Bacteroidetes and candidate division OP8. The class Betaproteobacteria (37.9\%) was the most frequently detected lineage at all depth intervals. The percentage of this group changed with depth from about $29.3 \%$ within the surface clay-rich layers to $53.8 \%$ after $400 \mathrm{~cm}$ within turbidites (Fig. 3b). Sequences related to the class Betaproteobacteria grouped within four families (Oxalobacteraceae, Burkholderiaceae, Ralstoniaceae and Comamonadaceae) and the most abundant families were the Ralstoniaceae (16.1\%), followed by Comamonadaceae $(7.7 \%)$. Within these families, sequences were affiliated to the genera Ralstonia and Comamonas, two key taxa of soil microbial communities capable of degrading recalcitrant compounds. The phyla Gammaproteobacteria $(12.1 \%$ of total) and Bacteroidetes (8.7\%) comprised, respectively, one family (Moraxellaceae) and two families (Sphingobacteriaceae and Flavobacteriaceae), and were distributed at different depths within this core. At this site, sequences were closely related to environmental sequences or isolates originating from soil (Zinger et al., 2009), groundwater, waste water (Gomila et al., 2007), mines (Sahl et al., 2008) and mining lakes (Kampe et al., 2010). Most of them were related to strains able to degrade several classes of recalcitrant compounds. Another group retrieved only at this site was the 
phylum Chloroflexi that encompassed $4.7 \%$ of the bacterial diversity. All detected sequences belonged to the subdivision II of this phylum (Hugenholtz et al., 1998) and were mainly present at shallow depths (from $3 \mathrm{~cm}$ to $286 \mathrm{~cm}$ ) in layers dominated by clay or silty-clay. These sequences were most closely related to clones obtained from marine subsurface sediments of Pacific Ocean margin (Inagaki et al., 2006), Gulf of Mexico (Nunoura et al., 2009) and from tidal flat sediments from the Wadden Sea (Wilms et al., 2006) (over $95 \%$ sequence similarity). The closest cultured relative to our sequences was the bacterium Dehalogenimonas lykanthroporepellens strain BL-DC-9, with a sequence similarity of $89 \%$, a strain capable of reductively dehalogenating 1,2,3trichloropropane (Yan et al., 2009). Details for sequence similarities of excised DGGE bands are available as Supplement information (Fig. S4-6).

\subsection{Microbial cultures}

In this study, two cultivation strategies were used. (i) First, enrichment cultures were performed from three depth intervals on the RHS-KS-33 core to isolate a broad spectrum of physiological types of marine microorganisms (Table 1). (ii) Then, after we highlighted the dominance of Betaproteobacteria at both studied sites, a specific culture medium was designed (see Methods section) and enrichment assays were performed at different depth intervals on both studied cores (Fig. 3) in order to cultivate representatives of this group. Generally, growth was detected at both sites, and a total of 75 strains were isolated on various substrates and cultivation conditions. Phylogenetic analyses revealed that the strains belonged to four lineages: Alpha-, Gammaproteobacteria, Firmicutes and Actinobacteria. In core RHS-KS-33, the largest number of isolates affiliated with the Gammaproteobacteria (54 strains, $73.97 \%$ of the culture collection, Table 1). Most of them were closely related to the genera Halomonas (23 strains), Pseudoalteromonas (15 strains) and Marinobacter (9 strains), with over $99 \%$ sequence similarity. In core RHS-KS-33, the results obtained in aerobic rich and selective solid media showed the presence of a larger diversity of cultivated prokaryotes at shallow depths than at the bottom of the core. Several liquid enrichment cultures targeting nitrate reducers or sulfate-reducers were obtained but could not be maintained until isolation, and no positive enrichment was obtained for methanogens. In contrast, all enrichment cultures designed for the growth of fermentative microorganisms were positive with a high turbidity, indicating the presence of this physiological group at each depth interval. Unexpectedly, cultures made on the modified $\mathrm{R} 2 \mathrm{~A}$ medium at $25^{\circ} \mathrm{C}$ did not allow isolating members of the class Betaproteobacteria. Phylogenetic analysis revealed that the isolated strains on this medium belonged to the lineages Gammaproteobacteria, Firmicutes and Actinobacteria (Table 1).

\subsection{Bacterial community structure and ecological analysis of physicochemical variables}

We first performed CCA using all physicochemical parameters as constrained variables of the bacterial community diversity from DGGE fingerprints of Gulf of Lion core RHSKS-33 samples. A strong Spearman's rank pairwise correlation between $\mathrm{Ba}$ and $\mathrm{Sr} / \mathrm{Ca}(R=0.92, p<0.01)$ allowed us to use barium as a proxy of strontium/calcium to perform CCA together with the other physicochemical parameters. We found that $44.8 \%$ of changes in the DGGE profiles could be explained by a set of physicochemical parameters including $\mathrm{S}, \mathrm{MgO}, \mathrm{Sr}, \mathrm{Ba}$ and to a lesser extend $\mathrm{Ni}$ and K/Al (Table 2 and Fig. 4). The cumulative percentage of the first two canonical axes accounted for $57.3 \%$ of this variance (Table 2). Subsequent axes accounted for less than $13 \%$ of the variance each, and were not considered further. The first canonical axis was highly negatively correlated to sulfate (ca. -0.75), to a lesser extent to barium (ca. -0.5), and slightly positively correlated to strontium and potassium/aluminum (ca. 0.2). This first synthetic gradient clearly separated deep samples (below $500 \mathrm{~cm}$ ) from shallower samples (from the top to $350 \mathrm{~cm}$ ), indicating that their community composition varied with different concentrations of these chemical species. The second canonical axis was highly positively correlated with nickel and magnesium, clearly separating depth intervals (around $200 \mathrm{~cm}$ and around $400 \mathrm{~cm}$ ) (Fig. 4). The total variance of fitted Ligurian Sea core KESC9-30 sample DGGE data when using several variables such as sulfate, age, iron, manganese, strontium and titanium/calcium was $28.7 \%$ (Table 2). The cumulative percentage of variance of the species-environment relationship indicates that the first and second canonical axes account for $24.4 \%$ and $45.2 \%$ of this variance, respectively. The first canonical axis was highly positively correlated with sulfate (ca. 0.80), to a lesser extent with iron, manganese, strontium, titanium/calcium $(<0.4)$, and highly negatively correlated with age (ca. -0.80$)$. For this core, Spearman's rank pairwise correlation revealed that $\mathrm{Ti} / \mathrm{Ca}$ was a proxy for $\mathrm{Fe} / \mathrm{Ca}, \mathrm{Ca} / \mathrm{Al}$ and $\mathrm{Al}_{2} \mathrm{O}_{3} ; \mathrm{Fe}_{2} \mathrm{O}_{3}$ was a proxy for $\mathrm{Zn}$ and $\mathrm{TiO}_{2}$ (Fig. 4). The first observed gradient clearly confirmed that the age of the sediments (which is also related to the source of sediments) clearly influences the structure and the composition of bacterial communities below $400 \mathrm{~cm}$. At shallower depths (100$300 \mathrm{~cm}$ ), we observed that the bacterial community structure was driven by factors other than the sedimentary dynamics, such as sulfate concentration and to a lesser extent some metal concentrations (Fig. 4).

\section{Discussion}

The study of a well-characterized area represents an opportunity to use numerous environmental data sets, contrary to exploratory surveys. In this respect, the continuous 
Table 2. Summary of the results from canonical correspondence analyses of the bacterial community structure data when constrained by environmental variables.

\begin{tabular}{|c|c|c|c|c|}
\hline Environmental variables & \multicolumn{2}{|c|}{ RHS-KS-33 } & \multicolumn{2}{|c|}{ KESC9-30 } \\
\hline Total inertia & \multicolumn{2}{|c|}{1.754} & \multicolumn{2}{|c|}{3.703} \\
\hline Sum of all canonical eigenvalues & \multicolumn{2}{|c|}{0.783} & \multicolumn{2}{|c|}{1.061} \\
\hline CCA explained variability* & \multicolumn{2}{|c|}{$44.74 \%$} & \multicolumn{2}{|c|}{$28.65 \%$} \\
\hline & Axis 1 & Axis 2 & Axis 1 & Axis 2 \\
\hline Eigenvalues & 0.269 & 0.180 & 0.231 & 0.198 \\
\hline Species-environment correlations & 0.905 & 0.810 & 0.900 & 0.833 \\
\hline $\begin{array}{l}\text { Cumulative percentage variance } \\
\text { of species data }\end{array}$ & \multicolumn{3}{|c|}{ Cumulative percentage variance } & 11.6 \\
\hline of species-environment relation & 34.3 & 57.3 & 24.4 & 45.2 \\
\hline Monte Carlo test & F-ratio: & -value: 0.002 & F-ratio: & P-value: 0.002 \\
\hline
\end{tabular}

* Sum of all canonical eigenvalues/Total inertia

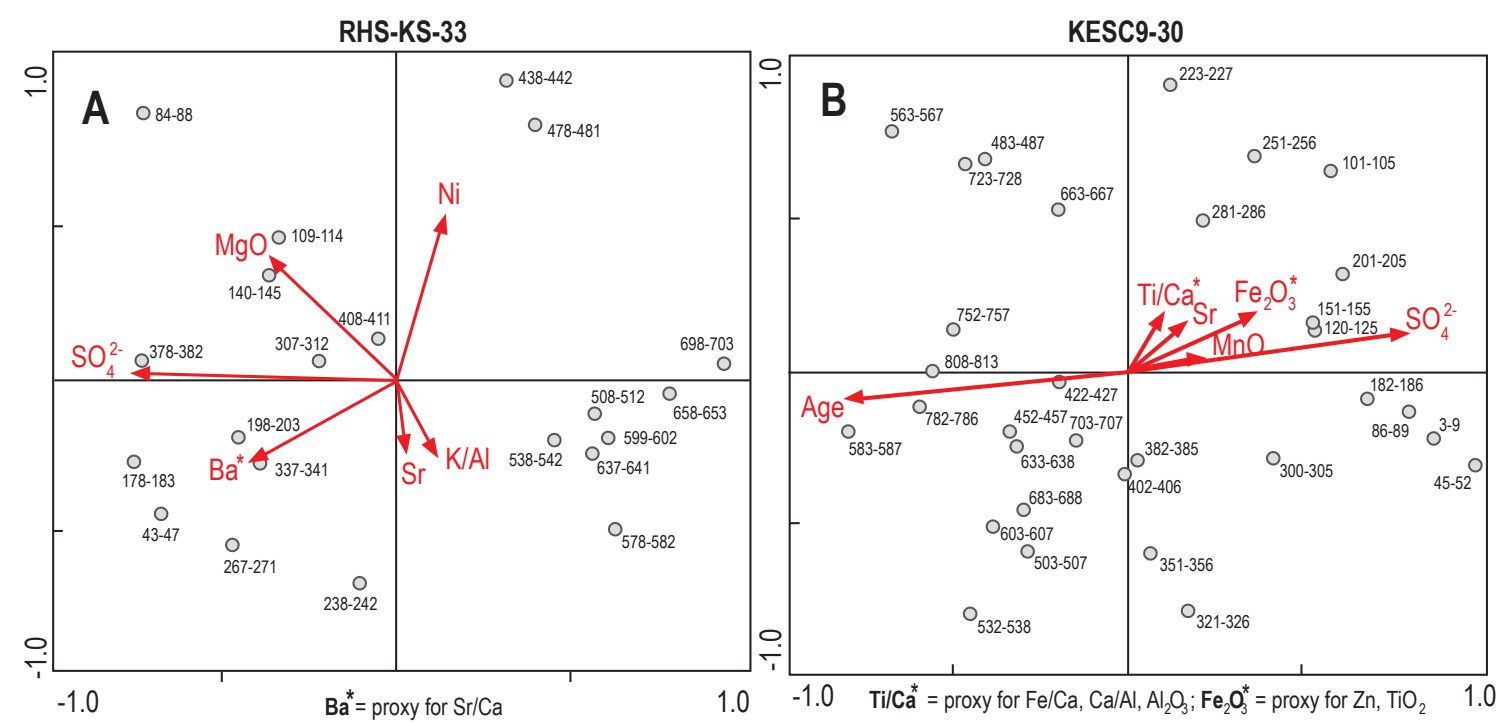

Fig. 4. Canonical correspondence analysis (DGGE bands intensity) of bacterial community structure from core RHS-KS-33 and core KESC930. Red arrows point in the direction of increasing values of each variable. The length of the arrows indicates the degree of correlation with the represented axes. The position of samples relative to arrows is interpreted by projecting the points perpendicularly on the arrow and indicates the extent to which a sample is influenced by the environmental parameter represented by that arrow. Samples from different depth intervals are indicated by light grey circles.

and well-preserved depositional environment of the Western Mediterranean Sea is particularly well-documented (Rabineau et al., 2005). Thus, the cores RHS-KS-33 and KESC9-30 investigated here could be compared with several reference cores from the Gulf of Lion and the Ligurian Sea collected at the same water depth, showing that these cores are representative of their depositional settings (i.e. upper slope and deep levee, respectively).

The vertical distribution of communities in marine subsurface sediments of the Western Mediterranean Sea was investigated by the DGGE fingerprinting method that allows processing and analysis of a great number of samples in a reproducible way. This technique is commonly used in microbial ecology and is quite sensitive. However, this tool has some limitations: it is potentially affected by PCR-inherent biases, by the presence of multiple band patterns for a single species (Nübel et al., 1996), or by the occurrence of dissimilar sequences that may develop a co-migrating behavior within a DGGE gel (Rossello-Mora et al., 1999). Even so, DGGE is a powerful tool for rapid monitoring of successive changes within microbial communities. In this study, bacterial DGGE profiles, statistical analyses with environmental parameters, and excision and sequencing of DGGE bands allowed us to observe several changes in the microbial community structure and composition of subsurface sediments in the Western Mediterranean Sea linked to changes in environmental conditions since the Last Glacial Maximum (LGM), as described hereafter. 


\subsection{A microbial diversity impacted by the paleoenvironmental conditions and the geochemical sediment and pore water compositions}

The results of this study provide insights into identities of predominant microorganisms at two contrasted sites from the Western Mediterranean Sea. The total cell numbers in surface layers at both studied locations were generally one or two orders of magnitude lower compared to the universal depth distribution of subsurface bacterial populations proposed by Parkes et al. (2000) (Fig. 3). The possible environmental factors that control biomass, diversity and activity of subseafloor microbial communities have been previously discussed (Jørgensen and D'Hondt, 2006), and the importance of organic compounds driving microbial community densities in subseafloor sediments has often been pointed out (Lipp et al., 2008). These low cell number values might be explained by the very low TOC contents (less than $0.5 \%$ ) and by the quality of the organic matter (OM). A paradigm commonly seen in the literature is that terrigenous OM (decaying vegetation and fauna) is highly refractory in comparison to native marine OM (phytoplankton production) (Hedges et al., 1997). This might be the case here. At the present time, the role of terrigenous organic matter and its fate in the ocean is still a subject of current debate (Benner, 2004).

The structure and the composition of archaeal and bacterial assemblages in these samples are diverse and very different from those encountered in other deep-sea sediment settings and locations within the Mediterranean Sea, such as surficial sediments (first centimeters) (Polymenakou et al., 2005b; Polymenakou et al., 2009), mud volcanoes (Lazar et al., 2011) and brines (La Cono et al., 2011).

\subsubsection{Archaeal diversity}

Fingerprinting analysis of archaeal and bacterial communities at both study sites revealed that the archaeal OTU (operational taxonomic units) number was much lower than that for Bacteria, which is consistent with the shallow depth of these subseafloor sediments (Danovaro et al., 2010 and references therein). Besides, archaeal diversity seems to be closely influenced by the lithological structure. Core RHSKS-33, which is characterized by a homogenous distribution of facies, was dominated by a single archaeal group (the MCG). On the other hand, core KESC9-30, characterized by heterogeneous facies, was dominated by nine different archaeal clusters. The archaeal diversity of both studied sites was typical for marine sediments, represented by widely distributed and typical subseafloor groups. MCG dominated the archaeal diversity at both sites. MCG were consistently found in marine sediments from different locations, notably from the Peru margin (organic carbon rich, sites 1227, 1228, 1229) (Parkes et al., 2005; Inagaki et al., 2006; Sørensen and Teske, 2006; Webster et al., 2006) and the Sea of Okhotsk (ash layers) (Inagaki et al., 2003).
They are likely to be heterotrophic anaerobes capable of using complex organic substrates (Teske and Sørensen, 2008), and this may explain why they are so widely distributed in marine and terrestrial systems (Teske and Sørensen, 2008). Likewise, members of other archaeal clusters previously found in deep marine/terrestrial sediments such as SAGMEG, MBGB, MBGC, MBGD and MGI (Fry et al., 2008; Teske and Sørensen, 2008) were also found in the Ligurian Sea, at different depths, with various sediment compositions (Fig. 3).

\subsubsection{Bacterial diversity}

In general, the bacterial DGGE libraries were very diverse at both sites. Ubiquitous lineages such us Betaproteobacteria,Bacteroidetes and Gammaproteobacteria were present at both sites, while Actinobacteria and Firmicutes were detected only in the Gulf of Lion and Chloroflexi only in the Ligurian Sea. This diversity is similar with diversities found in other studies on Eastern Mediterranean Sea sediments in which bacterial clone libraries were dominated by Alpha-, Gamma-, Deltaproteobacteria, Acidobacteria, Planctomycetes, Actinobacteria, Bacteroidetes, and a few Verrucomicrobia, Firmicutes, Betaproteobacteria, and Chloroflexi (Polymenakou et al., 2005b; Polymenakou et al., 2009). Nevertheless, Deltaproteobacteria, Planctomycetes and Verrucomicrobia were not detected in this survey. Considering that the DGGE method detects preferentially the dominant groups, these groups may not be dominant in this region. Our results indicate that bacterial assemblages from the Western Mediterranean Sea sediments (dominated by $\mathrm{Be}$ taproteobacteria) are very different from those encountered in the Eastern Mediterranean Sea sediments (dominated by Acidobacteria). This finding is in agreement with previous studies where significant longitudinal differences were observed between the Western, Central and Eastern Mediterranean Sea, indicating a high regional variability (Polymenakou et al., 2005b, a; Heijs et al., 2008; Danovaro et al., 2010). One possible explanation is that microbial communities in coastal subseafloor environments are strongly influenced by geological and geochemical settings (Inagaki et al., 2006; Nunoura et al., 2009; Danovaro et al., 2010). Furthermore, the difference in depositional environments, which reflects the source and the bioavailability of organic carbon, may explain the different microbial communities in the Gulf of Lion and the Ligurian Sea (Nunoura et al., 2009). The consistent occurrence of a typical terrestrial group (Betaproteobacteria) at the two studied sites is surprising since both sites have never been emerged despite sea-level changes.

\subsubsection{Cultures}

The cultivation-based survey demonstrated that aerobic heterotrophs, fermenters, nitrate-reducers and sulfate-reducers were present in the Gulf of Lion. The collection of bacterial 
strains isolated from the Gulf of Lion was represented by mesophilic or psychrophilic aerobic heterotrophs belonging to the Gamma- and the Alphaproteobacteria. These results are consistent with in situ temperatures, estimated to be between $13-14{ }^{\circ} \mathrm{C}$. The cultivation of aerobic or facultative anaerobic strains from deep sediment layers has already been reported in the literature from samples collected between 77 and $420 \mathrm{~m}$ b.s.f (Batzke et al., 2007; Parkes et al., 2009). In this study, the isolation of bacterial strains under aerobic conditions from anoxic sediments may be explained by the fact that some of these strains are facultative anaerobes (e.g. Halomonas, Marinobacter, Alcanivorax) or that they are true aerobes that were inactive in situ (i.e. "in dormancy"). Within the Gammaproteobacteria, most of the isolates were affiliated to the genus Halomonas, a ubiquitous halotolerant microorganism. Unexpectedly, five isolates of Alphaproteobacteria were distantly related to their closest cultured representative (below 98.7\% 16S rRNA similarity, the threshold value for the delineation of a new species) (Stackebrandt and Ebers, 2006), indicating that these strains represent novel species (Table 1). Even though the microbial abundances and the total organic carbon content at both sites are quite low, both studied sites may support a heterotrophic microbial ecosystem, since a predominance of strains and sequences affiliated with heterotrophic taxa have been recovered. Molecular inventories have revealed the presence of numerous sequences affiliated with environmental clones from hydrocarbon-polluted or metal-contaminated habitats, and cultures led to the isolation of several heterotrophic taxa known for their ability to degrade refractory substrates (e.g. Marinobacter, Halomonas), suggesting that refractory substrates may somehow support this low biomass microbial ecosystem. Molecular and cultural approaches gave the same results at the phylum level but showed numerous differences at the family level, as already observed in different locations (Fry et al., 2008 and references therein).

\subsubsection{CCA analysis}

A major issue of this study was to determine whether changes in dominant bacterial community structure with depth in the sediment cores were driven by their depositional paleoenvironment. Our CCA analysis regrouped bacterial communities according to their vertical distribution, driven by several combinations of environmental parameters specific to each site (Fig. 4). Changes in bacterial community composition at the top of the Gulf of Lion core RHS-KS-33 were likely influenced by the pore water sulfate concentration and lithological structure (presence of sand in the upper $20 \mathrm{~cm}$ only), and obviously by the availability of oxidants that can serve as terminal electron acceptors for respiration. Middle depth distributions seem to be influenced by concentrations in magnesium and nickel, two nutrients taken up by microorganisms from rocks and soils (Gadd, 2010) that might be here influenced by the origin of the sedimentary material (fluvial, ma- rine). Depth distributions below $500 \mathrm{~cm}$ were influenced by strontium and potassium/aluminum, used to trace sediment sources, as these elements are present only in soil minerals (silicates) (Yarincik et al., 2000). In the Gulf of Lion, minerals such as micas (silicates) are common and were found in the twin core MD99-2348 (Rabineau et al., 2005). Distribution of bacterial communities in the Ligurian Sea is strongly influenced by the pore water sulfate concentrations at the top of the core, while below $400 \mathrm{~cm}$ it is mostly impacted by the sediment age which reflects the high frequency of turbidites (Figs. 4, 5).

The availability of electron acceptors (sulfate and metal oxides), the quality of electron donors (indicated by age) and the lithological structure (e.g. grain size, mineral composition, sedimentation rate) seem to constrain the stratification of microbial communities from the Mediterranean Sea sediments. This result was previously observed elsewhere (Inagaki et al., 2006). Moreover, these results seem to be linked to paleoenvironmental conditions via sediment structure, organic matter quality and geochemical composition of sediments.

\subsection{Imprint of climatic events on the microbial community structure/composition}

\subsubsection{Quaternary Climatic changes in the Western Mediterranean Sea}

During the Quaternary, essential climate changes took place in Western Europe with the occurrence of large glaciations and major changes in sea level, air temperature, humidity, vegetation, and oceanic currents that strongly impacted marine and terrestrial ecosystems. The two climatic extremes are represented by glacial periods with cold climate and low sea levels, and interglacial periods with warm climate and high sea levels. During the Last Glacial Maximum (LGM; 18-26 ka cal BP), mountain glaciers covered a large part of the Alps, and smaller glaciers also existed in the Pyrenees and the Massif Central (Fig. 1b) (Antoine et al., 1999; Hinderer, 2001). The mountain glaciers generated significant physical erosion episodes, providing important volumes of sediments of various grain sizes that were transported by rivers and ultimately deposited in the Gulf of Lion and the Ligurian Sea. Throughout the last glacial period, extreme cold events named Heinrich events were recurrent every 7 $10 \mathrm{ka}$ (named Heinrich 1 to 5 for the last $50 \mathrm{ka}$ ) (Heinrich, 1988) (Fig. 5a, g). These events, identified in the North Atlantic Ocean and North Sea sediments as ice-rafted detritus rich layers deposited from massive iceberg calving, were related to rapid retreat of ice sheets (Bond et al., 1992). At the time of Heinrich events, the prodigious amounts of freshwater added to the North Atlantic also resulted in a decrease in sea surface temperature and salinity in the Western Mediterranean Sea (Sierro et al., 2005). The LGM was followed by a rapid warming and deglaciation initiated at $19 \mathrm{ka}$ cal BP 

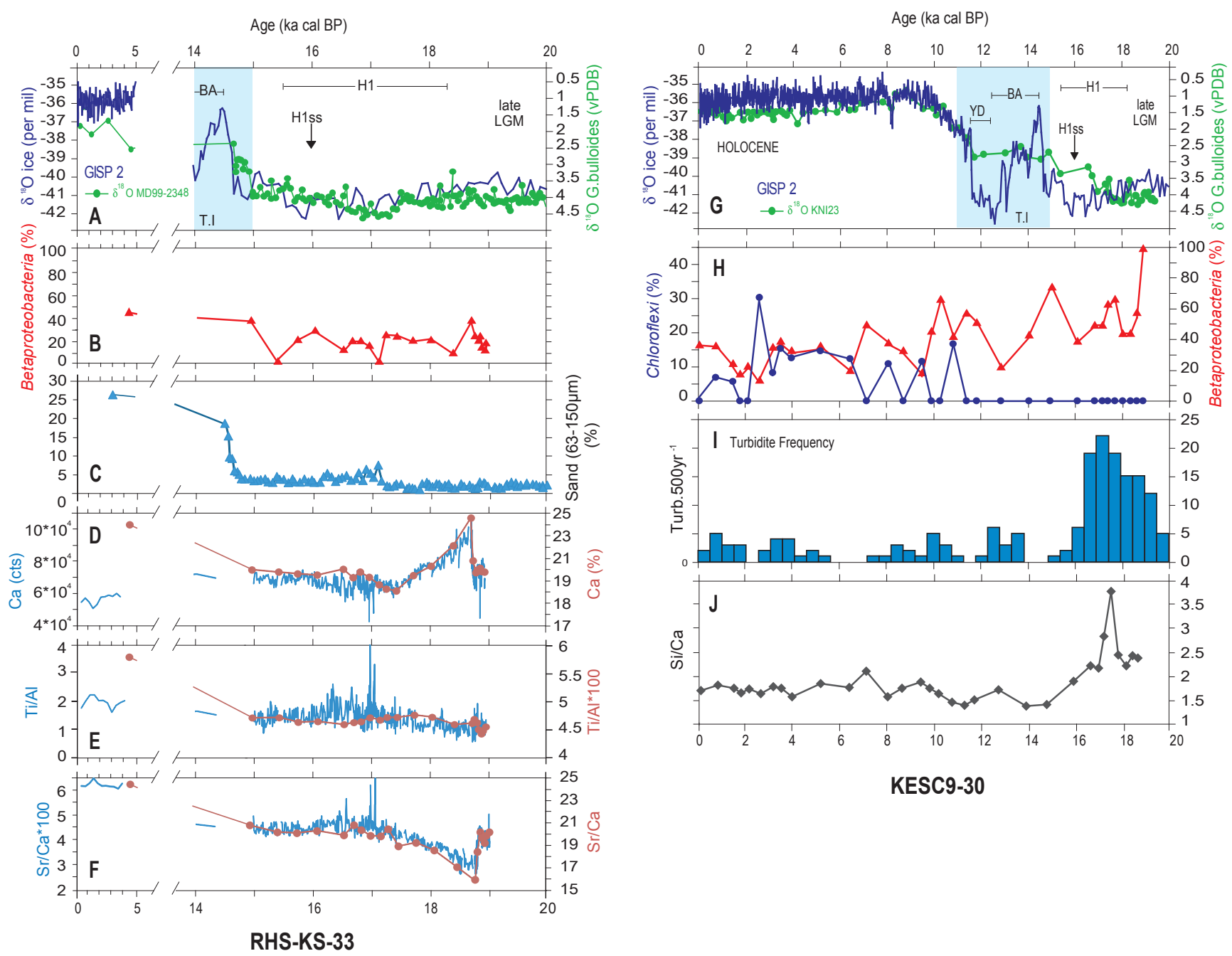

Fig. 5. Distribution of Betaproteobacteria during the Last Glacial Maximum and the Holocene in marine sediments from Western Mediterranean Sea (Ligurian Sea and Gulf of Lion). (A, G) GISP2 curve (blue), $\delta^{18}$ O curves (green): (A) modified from (Sierro et al., 2009), (G) modified from (Jorry et al., 2011). (B) Distribution of Betaproteobacteria during the last $20 \mathrm{ka}$. (C) Distribution of sand (63-150 $\mu \mathrm{m})$ during the last $20 \mathrm{ka}$. (D) Distribution of Ca concentrations during the last $20 \mathrm{ka}$. (E) Distribution of the ratio Ti/Al during the last $20 \mathrm{ka}$. (F) Distribution of the ratio $\mathrm{Ca} / \mathrm{Sr}$ during the last 20,ka. (H) Distribution of Betaproteobacteria and Chloroflexi during the last $20 \mathrm{ka}$. (I) Turbidite frequency of overflow deposits observed on the Var Sedimentary Ridge. (J) Distribution of the ratio Si/Ca during the last $20 \mathrm{ka}$. Abbreviations: late LGM, late Last Glacial Maximum (21 to $18.3 \mathrm{ka} \mathrm{cal} \mathrm{BP}$ ); H1, Heinrich 1 (15.5 to $18.3 \mathrm{ka}$ cal BP, as defined in Bard et al. (2000)); H1ss, Heinrich 1 stricto sensu (centered at $16 \mathrm{ka}$ cal BP, as defined in Heinrich (1988) and in Bard et al. (2000)); BA, Bølling-Allerød interval (between 14.5 and $12.5 \mathrm{ka}$ cal BP; warm interval); YD, Younger Dryas ( 12.5-11.5 ka cal BP; cold interval) (Bard et al., 2000; Hughen et al., 2000; Alley et al., 2003; Weaver et al., 2003); T.I, last climatic termination (blue block); cts, counts; ka cal BP, calibrated kilo annum Before Present.

(Clark et al., 2004), with sea-level rise leading to present day interglacial conditions. This glacial to interglacial transition (named the last termination (T.I)) is of crucial importance because drastic changes occurred over a short period (from about 15 to $11 \mathrm{kacal} \mathrm{BP}$ ). However, the warming and deglaciation since the LGM has not been linear, with some very rapid climate oscillations (Fig. 5a, g). Our investigations on Western Mediterranean sediments suggest that climatic events of the last $20 \mathrm{ka}$ indirectly influenced the structure and composition of microbial communities.

\subsubsection{Ligurian Sea}

As already mentioned in the previous chapter, climatic events of the last $20 \mathrm{ka}$ might indirectly influence the distribution of microbial communities at this site. One piece of evidence for this hypothesis lies in the correlation between the Betaproteobacteria distribution and the high amount of frequent turbidites during LGM to the beginning of Holocene (10 ka) in marine deep sediments. Most Betaproteobacteria live in soil and freshwater environments (Methe et al., 1998), and 
only a small fraction are present in marine environments (Parkes et al., 2005), even in coastal sediments (Wilms et al., 2006; Fry et al., 2008). Unexpectedly, because the depositional environment of KESC9-30 is definitively a deep marine environment $(2160 \mathrm{~m})$ and was deep even during the LGM, we discovered a high percentage of Betaproteobacteria in the DGGE sequences of KESC9-30 sediments. When Betaproteobacteria are plotted against age, according to the age model previously described, one can observe that the relative abundance of this group increases within turbidites (20 to $11 \mathrm{kacal} \mathrm{BP}$ ) (Fig. 5h). The Var turbiditic system results from the short connection between terrigenous sources and canyons, which explains high sedimentation rates $(\sim$ $0.60 \mathrm{~m} \mathrm{ka}^{-1}$ ) (Piper and Savoye, 1993) recorded during the Holocene. Betaproteobacteria might have been transported by rivers and preserved for the last $20 \mathrm{ka}$ as extracellular DNA or as dead cells.

Furthermore, our attempts to cultivate this group were unsuccessful, which may signify that this group is maybe not active in marine sediments. In that case, Betaproteobacteria might represent relicts influenced by the terrigenous input. These findings are congruent with a previous study where more than $60 \%$ Betaproteobacteria were found in a marineoriginated shallow subsurface layer Wang et al. (2008) suggested that Betaproteobacteria were inoculated from the adjacent environments (terrestrial input through rainfalls) during historical events that influenced the sediment deposition in the area. Betaproteobacteria were shown to be dominant in other marine environments such as gas hydrate deposits from Cascadia margin (Marchesi et al., 2001) or deep subsurface sediments from the Nankai Trough (Newberry et al., 2004), but their presence in these habitats was not discussed by the authors. Interestingly, sequences closely related to hydrocarbon-degrading Betaproteobacteria (genus Ralstonia) were found in the ocean crust (Mason et al., 2010); this led us to hypothesize that widespread communities could maintain over time, under certain conditions, in marine environments.

On the contrary, when Chloroflexi relative abundance is plotted against age, this group is present only in the upper clay-rich sediment layers from $11 \mathrm{kacal}$ BP to present day, which corresponds to sedimentary sequences of marine origin with much fewer turbidites and more pelagic (typically marine) sediments (Fig. 5h). The majority of our sequences were affiliated with subdivision II of the Chloroflexi, a phylogenetic branch typical for deep subsurface habitats (Wilms et al., 2006). The detection of typical deep-biosphere bacteria such as the Chloroflexi in early Holocene marine sediments and Betaproteobacteria in LGM terrestrial-influenced sediments suggests that trends in microbial communities might reflect terrestrial vs. marine sediment inputs.

\subsubsection{Gulf of Lion}

The Gulf of Lion sedimentary sequence is complex, despite the homogeneous lithological structure, because sedimentation rates in the area are strongly influenced by changes in sea levels (Sierro et al., 2009). At this site, Holocene sediments are highly condensed. This is due to a drastic change (around $14.8 \mathrm{ka}$ ago) in the sedimentation rate from $2.5 \mathrm{~m} \mathrm{ka}^{-1}$ to less than $0.1 \mathrm{~m} \mathrm{ka}^{-1}$ in relation to a rapid sea-level rise and change of main depocenter from outer shelf to the innermiddle shelf (Fig. 5a and Fig. 1) (Rabineau et al., 2005; Sierro et al., 2009). During LGM, the shoreline was positioned on the outer shelf/upper slope (i.e. on the edge of the present day shelf break), so the river outlet was very near the position of core RHS-KS-33. We therefore studied if the bacterial community structure and composition were influenced by climatic events that occurred during the LGM and just after LGM (but without major change in physical parameters such as grain-size and porosity).

Within these sediments, betaproteobacterial communities (Fig. 5b) were less abundant than that encountered within the Ligurian Sea (Fig. 5h). Several peaks of Betaproteobacteria were observed during the LGM (Fig. 3 and Fig. 5b). In the Gulf of Lion, the LGM was characterized by the occurrence of cold and arid episodes (Heinrich events) (Jouet et al., 2006; Beaudouin et al., 2007). Between $20 \mathrm{ka}$ and $17 \mathrm{ka}$, the sea level was low, and marine sediments in the core were characterized by the proximity of the shoreline and the river mouth at that time and by a significant terrestrial input (Fig. 1) (Rabineau et al., 2005). As in the case of the Ligurian Sea, the terrestrial input seems to influence the composition of microbial communities since during this period the Betaproteobacteria relative abundances increased (Fig. 5b). A clear peak of Betaproteobacteria was observed around $18.7 \mathrm{ka}$, at the same time calcium concentrations also showed a very prominent peak (Fig. 5d). Calcium abundance can be related either to the marine realm (through the abundance of microfossils with calcitic skeleton, e.g. Foraminifera) or to the terrestrial realm when calcium exists in older compacted and outcropping sediments that can be transported by rivers. In our case, detailed studies of Foraminifera (Sierro et al., 2009) showed that their concentration increased drastically around $14.8 \mathrm{ka}$ when the sedimentation rate decreased and created a condensed layer rich in Foraminifera. This observation is also imaged in the grain size curve in Fig. 5c, since Foraminifera have a silt-sand size. Furthermore, this peak in Ca produced by Foraminifera occurred together with a peak in Sr. At $18.7 \mathrm{ka}$ (Fig. 5) an increase in grain size, in the amount of Foraminifera (Sierro et al., 2009), and in the amount of $\mathrm{Sr}$ was observed. As a consequence, we inferred a continental source for the observed Ca peak (Fig. 5d). This assumption is sustained by the pollen analysis made on the twin core that showed an important amount of reworked pollen at this depth $(5 \mathrm{~m}, 18.7 \mathrm{ka}$ with our age model) (Beaudouin et al., 2005; Sierro et al., 2009). The hypothesis of an 
increased terrestrial input is reinforced by two geochemical markers (Ti/Al, Fig. 5e, and Sr/Ca, Fig. 5f) commonly used in the literature to trace terrestrial sources in marine environments (Schnetger et al., 2000; Bayon et al., 2007). Elements present in detrital silicate minerals such as $\mathrm{Fe}$, Ti or $\mathrm{Al}$ showed increased values synchronous to the $\mathrm{Ca}$ peak (Fig. S2). However, the constancy of Ti/Al ratios in this interval strongly suggests that the composition of the silicate detrital fraction did not change (Fig. 5e). Nonetheless, the negative peak in $\mathrm{Sr} / \mathrm{Ca}$ ratios indicates an input of material that is relatively depleted in $\mathrm{Sr}$, strongly indicating a carbonate fraction of terrestrial origin (Fig. 5f).

These different lines of evidence suggest that sediments were discharged into the sea from a drainage basin with a high amount of carbonate, and that this carbonate was preferentially eroded at that time. We suggest that at the end of the LGM/beginning of $\mathrm{H} 1$ the Hérault canyon and interfluve area received sediments preferentially from the Hérault drainage basin, which had a higher amount of old carbonates, converse to what is observed at present where sediments mostly originate from the Rhône River (Révillon et al., 2011). This terrestrial source of carbonate sediment would also be prone to the increase of Betaproteobacteria. In this case, the presence of Betaproteobacteria is independent of grain size as core RHS-KS-33 is completely homogeneous. After the Ca peak, the presence of Betaproteobacteria remained non-negligible during the entire $\mathrm{H} 1$ event, with second order peaks that were difficult to interpret. Note that this site is much shallower than the Ligurian Sea site, so the position of the core is always under the influence of the river.

Generally, this study showed for both sites an unexpected high relative abundance of taxa with terrestrial microbial affinities within ancient lithological layers deposited in a marine environment. This result might be surprising considering the small size of microorganisms, the in situ porosity and the presence of pockmarks (fluid circulations) in the surrounding area of the core RHS-KS-33 (Fig. S7). Nevertheless, microbial surfaces necessarily interact with abiotic surfaces through weak interactions (e.g. van der Waals, hydrogen, ionic), and this could explain why microbial communities maintained, at least partially, their composition since sediment deposition despite fluid circulations.

\subsubsection{Preservation of DNA or dead cells in marine sediments?}

Some taxa could be successfully cultured using low salinity medium (modified R2A medium), indicating either the occurrence of taxa of terrestrial origin or the presence of taxa with a large salinity range (e.g. Halomonas sp., Pseudomonas sp.). Conversely, as Betaproteobacteria could not be isolated from our samples, Betaproteobacteria sequences might come from fossilized DNA or dead cells entrapped in place since 10-20 ka. The long-term preservation of DNA and/or microorganisms has repeatedly, and sometimes con- troversially, been reported during the last decade, from various field data from different environments (e.g. halite, amber, sediments, evaporites, water samples) in facies as old as 100 million years (Fish et al., 2002; Inagaki et al., 2005; Souza et al., 2006). In 2005, Inagaki et al. proposed that some molecular genetic reflections of the past may be somehow stored in a so-called "DNA Paleome" under specific conditions where degradations are minimized. The formation of organic-mineral complexes (e.g. clay, silica or calcite), resting stages, anoxia, low temperatures and neutral or alkaline $\mathrm{pH}$ favor the preservation of DNA or dead cells over long periods of time in marine sediments (Soina et al., 1994; Coolen and Overmann, 2007).

The interdisciplinary approach of this study does not allow us to conclude whether Betaproteobacteria were preserved as DNA-mineral complex or fossilized cells, but does support the hypothesis of the existence of a paleome. Consequently, we hypothesize that the subseafloor microbial communities at the Gulf of Lion and at the Ligurian Sea reflect to some degree a genetic imprint of ancient paleoenvironmental and paleoclimatic changes.

\section{Conclusions}

Our results indicate that the investigated Western Mediterranean Sea sediments in margin settings harbor a unique prokaryotic diversity different from that described in the Eastern Mediterranean Sea marine sediments and other spot locations within the Mediterranean Sea. Within the Western Mediterranean Sea, it seems that regional settings, such as sedimentary dynamics and fluxes from the continent, are controlling the prokaryotic diversity within marine sediments. The palaeoenvironmental history of erosion and deposition recorded in the Western Mediterranean Sea sediments appears to have left its imprint on the structure/composition of the microbial communities of the late Quaternary. Our findings demonstrate that molecular signatures of terrestrial microorganisms are dominant in the lithological marine sequences affected by terrestrial inputs. Future investigations will need to consider more sites and more comprehensive methods (e.g. RNA extractions, Q-PCR and metagenomics) to confirm the present findings. Such investigations will certainly provide new insights about the distribution of prokaryotic communities within marine sediments, and how these communities are influenced by the Earth history.

\section{Supplementary material related to this article is available online at: http://www.biogeosciences.net/9/ 3491/2012/bg-9-3491-2012-supplement..pfd.}


Acknowledgements. We thank the crew and the chief scientists of the 2008 cruises (RHOSOS: S. Berne and B. Dennielou, ESSCAR9: P. Woerther and J.-F. Bourillet) aboard the R/V Le Suroit for the core recoveries. We further thank G. Lericolais, head of the Laboratory of Sedimentary Environments of Ifremer for offering us the possibility to use the laboratory for the core description, and the technical team (G. Floch and M. Rovere) for assistance during splitting, photography and physical properties analysis. We would like to thank Francisco J. Sierro for providing the $\delta^{18} \mathrm{O}$ curve used in Fig. 5a. We are grateful to the editor Tina Treude for her very constructive comments. This work was financially supported by the Joint Research Unit UMR 6197 (CNRS-Ifremer-UBO), by the Joint Research Unit UMR 6538, by the projects SEDAAMIC I and SEDAMIC II funded by the program INTERRVIE 2011-2012 of the INSU (CNRS) and by the project PALEOMIC funded by the program "Projets Exploratoires 2011" of the Universite de Bretagne Occidentale (UBO). M.-C. Ciobanu was awarded with a $\mathrm{PhD}$ scholarship by the French Ministry of Research and CAREX Project (Coordination Action for Research Activities on Life in Extreme Environments).

Edited by: T. Treude

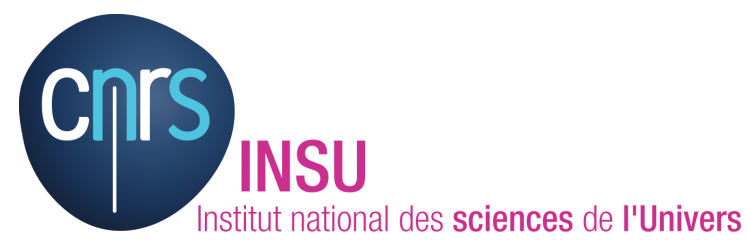

The publication of this article is financed by CNRS-INSU.

\section{References}

Akob, D. M., Mills, H. J., and Kostka, J. E.: Metabolically active microbial communities in uranium-contaminated subsurface sediments, FEMS Microbiol. Ecol., 59, 95-107, doi:10.1111/j.15746941.2006.00203.x, 2007.

Alain, K., Tindall, B. J., Intertaglia, L., Catala, P., and Lebaron, P.: Hellea balneolensis gen. nov., sp nov., a prosthecate alphaproteobacterium from the Mediterranean Sea, Int. J. Syst. Evol. Microb., 58, 2511-2519, doi:10.1099/ijs.0.65424-0, 2008.

Alain, K., Callac, N., Ciobanu, M.-C., Reynaud, Y., Duthoit, F., and Jebbar, M.: DNA extractions from deep subseafloor sediments: novel cryogenic-mill-based procedure and comparison to existing protocols, J. Microbiol. Meth., 87, 355-362, 2011.

Alley, R. B., Marotzke, J., Nordhaus, W. D., Overpeck, J. T., Peteet, D. M., Pielke, R. A., Pierrehumbert, R. T., Rhines, P. B., Stocker, T. F., Talley, L. D., and Wallace, J. M.: Abrupt climate change, Science, 299, 2005-2010, doi:10.1126/science.1081056, 2003.

Altschul, S. F., Gish, W., Miller, W., Myers, E. W., and Lipman, D. J.: Basic Local Alignment Search Tool, J. Mol. Biol., 215, 403410, doi:10.1016/s0022-2836(05)80360-2, 1990.

Antoine, P., De Beaulieu, J. L., Bintz, P., Brugal, J. P., Girard, M., Guadelli, J. L., Morzadec-Kerfourn, M. T., Renault-Miskovsky, J., Roblin-Jouve, A., Schmider, B., Van Vliet-Lanoe, B., and Vigne, J. D.: La france pendant les deux derniers extrêmes climatiques, variabilité naturelle des environnements, 59 pp., 1999.
Bard, E., Rostek, F., Turon, J. L., and Gendreau, S.: Hydrological impact of Heinrich events in the subtropical northeast Atlantic, Science, 289, 1321-1324, doi:10.1126/science.289.5483.1321, 2000.

Batzke, A., Engelen, B., Sass, H., and Cypionka, H.: Phylogenetic and physiological diversity of cultured deep-biosphere bacteria from equatorial Pacific Ocean and Peru Margin sediments, Geomicrobiol. J., 24, 261-273, doi:10.1080/01490450701456453, 2007.

Bayon, G., Pierre, C., Etoubleau, J., Voisset, M., Cauquil, E., Marsset, T., Sultan, N., Le Drezen, E., and Fouquet, Y.: Sr/Ca and $\mathrm{Mg} / \mathrm{Ca}$ ratios in Niger Delta sediments: Implications for authigenic carbonate genesis in cold seep environments, Mar. Geol., 241, 93-109, doi:10.1016/j.margeo.2007.03.007, 2007.

Baztan, J., Berne, S., Olivet, J. L., Rabineau, M., Aslanian, D., Gaudin, A., Rehault, J. P., and Canals, M.: Axial incision: The key to understand submarine canyon evolution (in the western Gulf of Lion), Mar. Petrol. Geol., 22, 805-826, doi:10.1016/j.marpetgeo.2005.03.011, 2005.

Beaudouin, C., Suc, J.-P., Acherki, N., Courtois, L., Rabineau, M., Aloïsi, J.-C., Sierro, F., Oberlin, C.: First Palynological results from the northwestern Mediterranean shelf (Gulf of Lions): a last climatic cycle vegetation record, Mar. Petrol. Geol., 22, 845-863, 2005.

Beaudouin, C., Jouet, G. L., Suc, J. P., Berne, S., and Escarguela, G.: Vegetation dynamics in southern France during the last $30 \mathrm{ky}$ BP in the light of marine palynology, Quat. Sci. Rev., 26, 10371054, doi:10.1016/j.quascirev.2006.12.009, 2007.

Beck, M., Riedel, T., Graue, J., Köster, J., Kowalski, N., Wu, C. S., Wegener, G., Lipsewers, Y., Freund, H., Böttcher, M. E., Brumsack, H.-J., Cypionka, H., Rullkötter, J., and Engelen, B.: Imprint of past and present environmental conditions on microbiology and biogeochemistry of coastal Quaternary sediments, Biogeosciences, 8, 55-68, doi:10.5194/bg-8-55-2011, 2011.

Benner, R.: What happens to terrestrial organic matter in the ocean?, Mar. Chem., 92, 307-310, doi:10.1016/j.marchem.2004.06.033, 2004.

Bond, G., Heinrich, H., Broecker, W., Labeyrie, L., McManus, J., Andrews, J., Huon, S., Jantschik, R., Clasen, S., Simet, C., Tedesco, K., Klas, M., Bonani, G., and Ivy, S.: Evidence for massive discharges of icebergs into the North-Atlantic ocean during the Last Glacial Period, Nature, 360, 245-249, doi:10.1038/360245a0, 1992.

Bruun, A. M., Finster, K., Gunnlaugsson, H. P., Nornberg, P., and Friedrich, M. W.: A Comprehensive Investigation on Iron Cycling in a Freshwater Seep Including Microscopy, Cultivation and Molecular Community Analysis, Geomicrob. J., 27, 15-34, doi:10.1080/01490450903232165, 2010.

Casamayor, E. O., Schäfer, H., Baneras, L., Pedros-Alio, C., and Muyzer, G.: Identification of and spatio-temporal differences between microbial assemblages from two neighboring sulfurous lakes: Comparison by microscopy and denaturing gradient gel electrophoresis, Appl. Environ. Microb., 66, 499-508, doi:10.1128/aem.66.2.499-508.2000, 2000.

Cauwet, G.: Non-living particulate matter, in: Marine Organic Chemistry - Evolution, Composition, Interactions and Chemistry of Organic Matter in Seawater, edited by: Series, E. O., 71-89, 1981. 
Clark, P. U., McCabe, A. M., Mix, A. C., and Weaver, A. J.: Rapid rise of sea level 19,000 years ago and its global implications, Science, 304, 1141-1144, doi:10.1126/science.1094449, 2004.

Coolen, M. J. L., and Overmann, J.: 217 000-year-old DNA sequences of green sulfur bacteria in Mediterranean sapropels and their implications for the reconstruction of the paleoenvironment, Environ. Microbiol., 9, 238-249, doi:10.1111/j.14622920.2006.01134.x, 2007.

Cord-Ruwish, R.: A quick method for the determination of dissolved and precipitated sulfides in cultures of sulfate-reducing bacteria., J. Microb. Meth., 4, 33-36, 1985.

Cragg, B. A., Harvey, S. M., Fry, J. C., Herbert, R. A., and Parkes, R. J.: Bacterial biomass and activity in tapan Sea, Hole 798B, Proc. Ocean Drilling Prog. Sci. Results, 127/128, 76he deep sediment layers of the J1-776, 1992.

D’Hondt, S., Jørgensen, B. B., Miller, D. J., Batzke, A., Blake, R., Cragg, B. A., Cypionka, H., Dickens, G. R., Ferdelman, T., Hinrichs, K. U., Holm, N. G., Mitterer, R., Spivack, A., Wang, G., Bekins, B., Engelen, B., Ford, K., Gettemy, G., Rutherford, S. D., Sass, H., Skilbeck, C. G., Aiello, I. W., Guerin, G., House, C. H., Inagaki, F., Meister, P., Naehr, T., Niitsuma, S., Parkes, R. J., Schippers, A., Smith, D. C., Teske, A., Wiegel, J., Padilla, C. N., and Acosta, J. L.: Distributions of microbial activities in deep subseafloor sediments, Science, 306, 2216-2221, 306/5705/2216 [pii] doi:10.1126/science.1101155, 2004.

Danovaro, R., Company, J. B., Corinaldesi, C., D’Onghia, G., Galil, B., Gambi, C., Gooday, A. J., Lampadariou, N., Luna, G. M., Morigi, C., Olu, K., Polymenakou, P., Ramirez-Llodra, E., Sabbatini, A., Sarda, F., Sibuet, M., and Tselepides, A.: Deep-Sea Biodiversity in the Mediterranean Sea: The Known, the Unknown, and the Unknowable, PLoS One, 5, e11832 doi:10.1371/journal.pone.0011832, 2010.

DeLong, E. F.: Archaea in coastal marine environments, Proceedings of the National Academy of Sciences of the United States of America, 89, 5685-5689, doi:10.1073/pnas.89.12.5685, 1992.

Ehlers, J.: Quaternary and Glacial Geology, Wiley, New York, 578 pp., 1996.

El Maghraoui, M., Joron, J. L., Etoubleau, J., Cambon, P., and Treuil, M.: Determination of forty four major and trace elements in GPMA magamtic rock reference samples using X-ray fluorescence spectrometry (XRF) and Instrumental Neutron Activation Analysis (INAA), Geostandards Newsletter, the journal of Geostandards and Geoanalysis, 23, 59-68, 1999.

Engelen, B., Ziegelmueller, K., Wolf, L., Kopke, B., Gittel, A., Cypionka, H., Treude, T., Nakagawa, S., Inagaki, F., Lever, M. A., and Steinsbu, B. O.: Fluids from the oceanic crust support microbial activities within the deep biosphere, Geomicrob. J, 25, 56-66, doi:10.1080/01490450701829006, 2008.

Fish, S. A., Shepherd, T. J., McGenity, T. J., and Grant, W. D.: Recovery of $16 \mathrm{~S}$ ribosomal RNA gene fragments from ancient halite, Nature, 417, 432-436, doi:10.1038/417432a, 2002.

Fromin, N., Hamelin, J., Tarnawski, S., Roesti, D., JourdainMiserez, K., Forestier, N., Teyssier-Cuvelle, S., Gillet, F., Aragno, M., and Rossi, P.: Statistical analysis of denaturing gel electrophoresis (DGE) fingerprinting patterns, Environ. Microbiol., 4, 634-643, 358 [pii], 2002.

Fry, J. C., Parkes, R. J., Cragg, B. A., Weightman, A. J., and Webster, G.: Prokaryotic biodiversity and activity in the deep subseafloor biosphere, FEMS Microbiol. Ecol., 66, 181-196, doi:10.1111/j.1574-6941.2008.00566.x, 2008.

Fulthorpe, C. S., Hoyanagi, K., Blum, P., and Scientists, E.: Methods: Geochemistry and microbiology, in: Proceedings of the Integrated Ocean Drilling Program, edited by: U.S. Implementing Organisation Services, T. A. M. U., Integrated Ocean Drilling Program Management International, Inc., Texas, 22-23, 2011.

Gadd, G. M.: Metals, minerals and microbes: geomicrobiology and bioremediation, Microbiology, 156, 609-643, mic.0.037143-0 [pii] doi:10.1099/mic.0.037143-0, 2010.

Gafan, G. P., and Spratt, D. A.: Denaturing gradient gel electrophoresis gel expansion (DGGEGE)-an attempt to resolve the limitations of co-migration in the DGGE of complex polymicrobial communities, FEMS Microbiol. Lett., 253, 303-307, S03781097(05)00685-3 [pii], doi:10.1016/j.femsle.2005.09.048, 2005.

Gaillard, C. and Strauss, F.: Ethanol precipitation of DNA with Linear Polyacrylamide as a carrier, Nucl. Acids Res., 18, 378-378, doi:10.1093/nar/18.2.378, 1990.

Ghiglione, J. F., Palacios, C., Marty, J. C., Mével, G., Labrune, C., Conan, P., Pujo-Pay, M., Garcia, N., and Goutx, M.: Role of environmental factors for the vertical distribution (0-1000 m) of marine bacterial communities in the NW Mediterranean Sea, Biogeosciences, 5, 1751-1764, doi:10.5194/bg-5-1751-2008, 2008.

Gomila, M., Bowien, B., Falsen, E., Moore, E. R., and Lalucat, J.: Description of Pelomonas aquatica sp. nov. and Pelomonas puraquae sp. nov., isolated from industrial and haemodialysis water, Int. J. Syst. Evol. Micr., 57, 2629-2635, 57/11/2629 [pii], doi:10.1099/ijs.0.65149-0, 2007.

Hedges, J. I., Keil, R. G., and Benner, R.: What happens to terrestrial organic matter in the ocean?, Org. Geochem., 27, 195-212, doi:10.1016/s0146-6380(97)00066-1, 1997.

Heijs, S. K., Laverman, A. M., Forney, L. J., Hardoim, P. R., and van Elsas, J. D.: Comparison of deep-sea sediment microbial communities in the Eastern Mediterranean, FEMS Microbiol. Ecol., 64, 362-377, doi:10.1111/j.1574-6941.2008.00463.x, 2008.

Heinrich, H.: Origin and consequences of cyclic ice rafting in the Northeast Atlantic-Ocean during the past 130,000 years, Quat. Res., 29, 142-152, doi:10.1016/0033-5894(88)90057-9, 1988.

Hinderer, M.: Late Quaternary denudation of the Alps, valley and lake fillings and 774 modern river loads., Geodinamica Acta, 14, 231-263, 2001.

Hugenholtz, P., Goebel, B. M., and Pace, N. R.: Impact of cultureindependent studies on the emerging phylogenetic view of bacterial diversity (vol 180, pg 4765, 1998), J. Bacteriol., 180, 67936793, 1998.

Hughen, K. A., Southon, J. R., Lehman, S. J., and Overpeck, J. T.: Synchronous radiocarbon and climate shifts during the last deglaciation, Science, 290, 1951-1954, doi:10.1126/science.290.5498.1951, 2000.

Inagaki, F., Suzuki, M., Takai, K., Oida, H., Sakamoto, T., Aoki, K., Nealson, K. H., and Horikoshi, K.: Microbial communities associated with geological horizons in coastal subseafloor sediments from the sea of okhotsk, Appl. Environ. Microbiol., 69, 7224-7235, 2003.

Inagaki, F., Okada, H., Tsapin, A. I., and Nealson, K. H.: Research paper: Microbial survival - The paleome: A sedimentary genetic record of past microbial communities, Astrobiology, 5, 141-153, doi:10.1089/ast.2005.5.141, 2005.

Inagaki, F., Nunoura, T., Nakagawa, S., Teske, A., Lever, M., Lauer, A., Suzuki, M., Takai, K., Delwiche, M., Colwell, F. S., 
Nealson, K. H., Horikoshi, K., D’Hondt, S., and Jørgensen, B. B.: Biogeographical distribution and diversity of microbes in methane hydrate-bearing deep marine sediments on the Pacific Ocean Margin, Proc. Natl. Acad. Sci. USA, 103, 2815-2820, 0511033103 [pii]10.1073/pnas.0511033103, 2006.

Jørgensen, B. B. and D'Hondt, S.: Ecology - A starving majority deep beneath the seafloor, Science, 314, 932-934, doi:10.1126/science.1133796, 2006.

Jorry, S. J., Jegou, I., Emmanuel, L., Jacinto, R. S., and Savoye, B.: Turbiditic levee deposition in response to climate changes: The Var Sedimentary Ridge (Ligurian Sea), Mar. Geol., 279, 148161, doi:10.1016/j.margeo.2010.10.021, 2011.

Jouet, G., Berne, S., Rabineau, M., Bassetti, M. A., Bernier, P., Dennielou, B., Sierro, F. J., Flores, J. A., and Taviani, M.: Shoreface migrations at the shelf edge and sea-level changes around the Last Glacial Maximum (Gulf of Lions, NW Mediterranean), Mar. Geol., 234, 21-42, doi:10.1016/j.margeo.2006.09.012, 2006.

Kallmeyer, J., Smith, D. C., Spivack, A. J., and D’Hondt, S.: New cell extraction procedure applied to deep subsurface sediments, Limnol. Oceanogr.-Meth., 6, 236-245, 2008.

Kampe, H., Dziallas, C., Grossart, H. P., and Kamjunke, N.: Similar Bacterial Community Composition in Acidic Mining Lakes with Different pH and Lake Chemistry, Microb. Ecol., 60, 618-627, doi:10.1007/s00248-010-9679-5, 2010.

La Cono, V., Smedile, F., Bortoluzzi, G., Arcadi, E., Maimone, G., Messina, E., Borghini, M., Oliveri, E., Mazzola, S., L'Haridon, S., Toffin, L., Genovese, L., Ferrer, M., Giuliano, L., Golyshin, P. N., and Yakimov, M. M.: Unveiling microbial life in new deep-sea hypersaline Lake Thetis. Part I: Prokaryotes and environmental settings, Environ. Microbiol., doi:10.1111/j.14622920.2011.02478.x, 2011.

Lane, D. J.: 16S/23S rRNA sequencing, in: Nucleic Acid Techniques, in: Bacterial Systematics, edited by: Stackebrandt, E., and Goodfellow, M., Wiley John \& Sons, New York, NY, 115175, 1991.

Lazar, C. S., Parkes, R. J., Cragg, B. A., L'Haridon, S., and Toffin, L.: Methanogenic diversity and activity in hypersaline sediments of the centre of the Napoli mud volcano, Eastern Mediterranean Sea, Environ. Microbiol., doi:10.1111/j.14622920.2011.02425.x, 2011.

Lipp, J. S., Morono, Y., Inagaki, F., and Hinrichs, K. U.: Significant contribution of Archaea to extant biomass in marine subsurface sediments, Nature, 454, 991-994, nature07174 [pii], doi:10.1038/nature07174, 2008.

Marchesi, J. R., Weightman, A. J., Cragg, B. A., Parkes, R. J., and Fry, J. C.: Methanogen and bacterial diversity and distribution in deep gas hydrate sediments from the Cascadia Margin as revealed by $16 \mathrm{~S}$ rRNA molecular analysis, FEMS Microbiol. Ecol., 34, 221-228, doi:10.1111/j.1574-6941.2001.tb00773.x, 2001.

Martiny, J. B., Bohannan, B. J., Brown, J. H., Colwell, R. K., Fuhrman, J. A., Green, J. L., Horner-Devine, M. C., Kane, M., Krumins, J. A., Kuske, C. R., Morin, P. J., Naeem, S., Ovreas, L., Reysenbach, A. L., Smith, V. H., and Staley, J. T.: Microbial biogeography: putting microorganisms on the map, Nat. Rev. Microbiol., 4, 102-112, nrmicro1341 [pii], doi:10.1038/nrmicro1341, 2006.

Mason, O. U., Nakagawa, T., Rosner, M., Van Nostrand, J. D., Zhou, J., Maruyama, A., Fisk, M. R., and Giovannoni, S. J.: First inves- tigation of the microbiology of the deepest layer of ocean crust, PLoS One, 5, e15399, doi:10.1371/journal.pone.0015399, 2010.

Methe, B. A., Hiorns, W. D., and Zehr, J. P.: Contrasts between marine and freshwater bacterial community composition: Analyses of communities in Lake George and six other Adirondack lakes, Limnol. Oceanogr., 43, 368-374, 1998.

Middelburg, J. J.: A simple rate model for organic-matter decomposition in marine-sediments, Geochim. Cosmochim. Ac., 53, 1577-1581, doi:10.1016/0016-7037(89)90239-1, 1989.

Migeon, S., Mulder, T., Savoye, B., and Sage, F.: The Var turbidite system (Ligurian Sea, northwestern Mediterranean) - morphology, sediment supply, construction of turbidite levee and sediment waves: implications for hydrocarbon reservoirs, GeoMarine Letters, 26, 361-371, 10.1007/s00367-006-0047-x, 2006.

Morono, Y., Terada, T., Masui, N., and Inagaki, F.: Discriminative detection and enumeration of microbial life in marine subsurface sediments, ISME J., 3, 503-511, ismej20091 [pii], doi:10.1038/ismej.2009.1, 2009.

Newberry, C. J., Webster, G., Cragg, B. A., Parkes, R. J., Weightman, A. J., and Fry, J. C.: Diversity of prokaryotes and methanogenesis in deep subsurface sediments from the Nankai Trough, Ocean Drilling Program Leg 190, Environ. Microbiol., 6, 274287, doi:10.1111/j.1462-2920.2004.00568.x, 2004.

Nübel, U., Engelen, B., Felske, A., Snaidr, J., Wieshuber, A., Amann, R. I., Ludwig, W., and Backhaus, H.: Sequence heterogeneities of genes encoding 16S rRNAs in Paenibacillus polymyxa detected by temperature gradient gel electrophoresis, J. Bacteriol., 178, 5636-5643, 1996.

Nunoura, T., Soffientino, B., Blazejak, A., Kakuta, J., Oida, H., Schippers, A., and Takai, K.: Subseafloor microbial communities associated with rapid turbidite deposition in the Gulf of Mexico continental slope (IODP Expedition 308), FEMS Microb. Ecol., 69, 410-424, doi:10.1111/j.1574-6941.2009.00718.x, 2009.

Parkes, R. J., Cragg, B. A., and Wellsbury, P.: Recent studies on bacterial populations and processes in subseafloor sediments: A review, Hydrogeol. J., 8, 11-28, doi:10.1007/p100010971, 2000.

Parkes, R. J., Webster, G., Cragg, B. A., Weightman, A. J., Newberry, C. J., Ferdelman, T. G., Kallmeyer, J., Jørgensen, B. B., Aiello, I. W., and Fry, J. C.: Deep sub-seafloor prokaryotes stimulated at interfaces over geological time, Nature, 436, 390-394, doi:10.1038/nature03796, 2005.

Parkes, R. J., Sellek, G., Webster, G., Martin, D., Anders, E., Weightman, A. J., and Sass, H.: Culturable prokaryotic diversity of deep, gas hydrate sediments: first use of a continuous high-pressure, anaerobic, enrichment and isolation system for subseafloor sediments (DeepIsoBUG), Environ. Microbiol., 11, 3140-3153, doi:10.1111/j.1462-2920.2009.02018.x, 2009.

Pautot, G.: Morphollogic framework of the Baie-des-Anges (Nicecôte-d'Azur) - Instability model of continental - slope, Oceanol. Ac., 4, 203-211, 1981.

Phuong, N. M., Kang, Y., Sakurai, K., Iwasaki, K., Kien, C. N., Noi, N., and Son, L. T.: Arsenic contents and physicochemical properties of agricultural soils from the Red River Delta, Vietnam, Soil Sci. Plant Nutr., 54, 846-855, doi:10.1111/j.17470765.2008.00312.x, 2008.

Piper, D. J. W. and Savoye, B.: Processes of late Quaternary turbidity current flow and deposition on the Var deep-sea fan, North-West Mediterranean Sea, Sedimentology, 40, 557-582, doi:10.1111/j.1365-3091.1993.tb01350.x, 1993. 
Polymenakou, P. N., Bertilsson, S., Tselepides, A., and Stephanou, E. G.: Links between geographic location, environmental factors, and microbial community composition in sediments of the Eastern Mediterranean Sea, Microb. Ecol., 49, 367-378, doi:10.1007/s00248-004-0274-5, 2005a.

Polymenakou, P. N., Bertilsson, S., Tselepides, A., and Stephanou, E. G.: Bacterial community composition in different sediments from the Eastern Mediterranean Sea: a comparison of four $16 \mathrm{~S}$ ribosomal DNA clone libraries, Microb. Ecol., 50, 447-462, doi:10.1007/s00248-005-0005-6, 2005b.

Polymenakou, P. N., Lampadariou, N., Mandalakis, M., and Tselepides, A.: Phylogenetic diversity of sediment bacteria from the southern Cretan margin, Eastern Mediterranean Sea, Syst. Appl. Microb., 32, 17-26, doi:10.1016/j.syapm.2008.09.006, 2009.

Rabineau, M., Berne, S., Aslanian, D., Olivet, J. L., Joseph, P., Guillocheau, F., Bourillet, J. F., Ledrezen, E., and Granjeon, D.: Sedimentary sequences in the Gulf of Lion: A record of 100,000 years climatic cycles, Mar. Petr. Geol., 22, 775-804, doi:10.1016/j.marpetgeo.2005.03.010, 2005.

Rabineau, M., Berne, S., Olivet, J.-L., Aslanian, D., Guillocheau, F., and Joseph, P.: Paleo sea levels reconsidered from direct observation of paleoshoreline position during Glacial Maxima (for the last 500,000 yr), Earth Planet. Sci. Lett., 252, 119-137, doi:10.1016/j.epsl.2006.09.033, 2006.

Rebata-Landa, V. and Santamarina, J. C.: Mechanical limits to microbial activity in deep sediments, Geochem. Geophys. Geosys., 7, Q11006 doi:10.1029/2006gc001355, 2006.

Révillon, S., Jouet, G., Bayon, G., Rabineau, M., Dennielou, B., Hemond, C., and Berné, S.: The provenance of sediments in the Gulf of Lions, western Mediterranean Sea, Geochem. Geophys. Geosyst., 12, Q08006 doi:10.1029/2011gc003523, 2011.

Richter, T. O., Van der Gaast, S. J., Koster, B., Vaars, A. J., Gieles, R., De Stigter, H. C., De Haas, H., and Weering, V.: The Avaatech XRF Core Scanner: technical description and applications to NE Atlantic sediments, in: New Techniques in Sediment Core Analysis., edited by: Rothwell, R. G., Geol. Soc., Special Publications, London, 39-50, 2006.

Rogers, J. R. and Bennett, P. C.: Mineral stimulation of subsurface microorganisms: release of limiting nutrients from silicates, Chemical Geology, 203, 91-108, doi:10.1016/j.chemgeo.2003.09.001, 2004.

Rossello-Mora, R., Thamdrup, B., Schäfer, H., Weller, R., and Amann, R.: The response of the microbial community of marine sediments to organic carbon input under anaerobic conditions, Syst. Appl. Microb., 22, 237-248, 1999.

Roussel, E. G., Sauvadet, A. L., Allard, J., Chaduteau, C., Richard, P., Bonavita, M. A. C., and Chaumillon, E.: Archaeal Methane Cycling Communities Associated with Gassy Subsurface Sediments of Marennes-Oleron Bay (France), Geomicrobiol. J., 26, 31-43, doi:10.1080/01490450802599284, 2009a.

Roussel, E. G., Sauvadet, A. L., Chaduteau, C., Fouquet, Y., Charlou, J. L., Prieur, D., and Bonavita, M. A. C.: Archaeal communities associated with shallow to deep subseafloor sediments of the New Caledonia Basin, Environ. Microbiol., 11, 2446-2462, doi:10.1111/j.1462-2920.2009.01976.x, 2009b.

Sahl, J. W., Schmidt, R. H., Swanner, E. D., Mandernack, K. W., Templeton, A. S., Kieft, T. L., Smith, R. L., Sanford, W. E., Callaghan, R. L., Mitton, J. B., and Spear, J. R.: Subsurface microbial diversity in deep-granitic-fracture water in Colorado,
Appl. Environ. Microbiol., 4, 143-152, doi:10.1128/aem.0113307, 2008.

Schnetger, B., Brumsack, H. J., Schale, H., Hinrichs, J., and Dittert, L.: Geochemical characteristics of deep-sea sediments from the Arabian Sea: a high-resolution study, Deep-Sea Res. Part II, 47, 2735-2768, doi:10.1016/s0967-0645(00)00047-3, 2000.

Schouten, S., Middelburg, J. J., Hopmans, E. C., and Damste, J. S. S.: Fossilization and degradation of intact polar lipids in deep subsurface sediments: A theoretical approach, Geochim. Cosmochim. Ac., 74, 3806-3814, doi:10.1016/j.gca.2010.03.029, 2010.

Selenska-Pobell, S., Kampf, G., Flemming, K., Radeva, G., and Satchanska, G.: Bacterial diversity in soil samples from two uranium waste piles as determined by rep-APD, RISA and $16 \mathrm{~S}$ rDNA retrieval, Antonie Van Leeuwenhoek, Int. J. General Mol. Microbiol., 79, 149-161, doi:10.1023/a:1010237711077, 2001.

Sierro, F. J., Hodell, D. A., Curtis, J. H., Flores, J. A., Reguera, I., Colmenero-Hidalgo, E., Barcena, M. A., Grimalt, J. O., Cacho, I., Frigola, J., and Canals, M.: Impact of iceberg melting on Mediterranean thermohaline circulation during Heinrich events, Paleoceanography, 20, Pa2019 10.1029/2004pa001051, 2005. v Sierro, F. J., Andersen, N., Bassetti, M. A., Berne, S., Canals, M., Curtis, J. H., Dennielou, B., Abel Flores, J., Frigola, J., Gonzalez-Mora, B., Grimalt, J. O., Hodell, D. A., Jouet, G., Perez-Folgado, M., and Schneider, R.: Phase relationship between sea level and abrupt climate change, Quat. Sci. Rev., 28, 2867-2881, doi:10.1016/j.quascirev.2009.07.019, 2009.

Soina, V. S., Vorobiova, E. A., Zvyagintsev, D. G., and Gilichinsky, D. A.: Preservation of cell structures in permafrost-A model for exobiology, in: Life Sciences and Space Research Xxv, edited by: Greenberg, J. M., Oro, J., Brack, A., Devincenzi, D. L., Banin, A., Friedmann, E. I., Rummel, J. D., Raulin, F., McKay, C. P., Baltscheffsky, H., Schwartz, A. W., Schidlowski, M., and Roessler, K., Adv. Space Res., 3, 237-242, 1994.

Sørensen, K. B., and Teske, A.: Stratified communities of active archaea in deep marine subsurface sediments, Appl. Environ. Microb., 72, 4596-4603, doi:10.1128/aem.00562-06, 2006.

Souza, V., Espinosa-Asuar, L., Escalante, A. E., Eguiarte, L. E., Farmer, J., Forney, L., Lloret, L., Rodriguez-Martinez, J. M., Soberon, X., Dirzo, R., and Elser, J. J.: An endangered oasis of aquatic microbial biodiversity in the Chihuahuan desert, P. Natl. Acad. Sci. USA, 103, 6565-6570, doi:10.1073/pnas.0601434103, 2006.

Stackebrandt, E. and Ebers, J.: Taxonomic parameters revisited: tarnished gold standards, Microbiol. Today, 152-155, 2006.

Teske, A. and Sørensen, K. B.: Uncultured archaea in deep marine subsurface sediments: have we caught them all?, ISME J., 2, 318, doi:10.1038/ismej.2007.90, 2008.

Wang, J. J., Wu, Y. C., Jiang, H. C., Li, C. H., Dong, H. L., Wu, Q. L., Soininen, J., and Shen, J.: High beta diversity of bacteria in the shallow terrestrial subsurface, Environ. Microbiol., 10, 25372549, doi:10.1111/j.1462-2920.2008.01678.x, 2008.

Weaver, A. J., Saenko, O. A., Clark, P. U., and Mitrovica, J. X.: Meltwater pulse 1A from Antarctica as a trigger of the bolling-allerod warm interval, Science, 299, 1709-1713, doi:10.1126/science.1081002, 2003.

Webster, G., Parkes, R. J., Cragg, B. A., Newberry, C. J., Weightman, A. J., and Fry, J. C.: Prokaryotic community composition and biogeochemical processes in deep subseafloor sedi- 
ments from the Peru Margin, FEMS Microbiol. Ecol., 58, 65-85, doi:10.1111/j.1574-6941.2006.00147.x, 2006.

Widdel, F., and Bak, F.: Gram-negative mesophilic sulphatereducing bacteria, in: The Prokaryotes, edited by: Balows, A., Trüper, H. G., Dworkin, M., Harder, W., and Schleifer, K.-H., Springer New-York, 3352-3378, 1992.

Wilms, R., Kopke, B., Sass, H., Chang, T. S., Cypionka, H., and Engelen, B.: Deep biosphere-related bacteria within the subsurface of tidal flat sediments, Environ. Microbiol., 8, 709-719, doi:10.1111/j.1462-2920.2005.00949.x, 2006.

Yamane, K., Maki, H., Nakayama, T., Nakajima, T., Nomura, N., Uchiyama, H., and Kitaoka, M.: Diversity and Similarity of Microbial Communities in Petroleum Crude Oils Produced in Asia, Bioscie. Biotechn. Biochem., 72, 2831-2839, doi:10.1271/bbb.80227, 2008.
Yan, J., Rash, B. A., Rainey, F. A., and Moe, W. M.: Isolation of novel bacteria within the Chloroflexi capable of reductive dechlorination of 1,2,3-trichloropropane, Environ. Microbiol., 11, 833-843, doi:10.1111/j.1462-2920.2008.01804.x, 2009.

Yarincik, K. M., Murray, R. W., and Peterson, L. C.: Climatically sensitive eolian and hemipelagic deposition in the Cariaco Basin, Venezuela, over the past 578,000 years: Results from Al/Ti and K/Al, Paleoceanography, 15, 210-228, doi:10.1029/1999pa900048, 2000.

Zinger, L., Shahnavaz, B., Baptist, F., Geremia, R. A., and Choler, P.: Microbial diversity in alpine tundra soils correlates with snow cover dynamics, ISME J., 3, 850-859, doi:10.1038/ismej.2009.20, 2009. 